\title{
KELEMBAGAAN DALAM SISTEM PERTANIAN PADI SEHAT
}

\author{
Hana Indriana ${ }^{*}$ Fredian Tonny, dan Nurmala K. Pandjaitan
}

Departemen Sains Komunikasi dan Pengembangan Masyarakat, Fakultas Ekologi Manusia, IPB

Email:hanaindriana@gmail.com

\begin{abstract}
Organic agriculture system has already developed and sustain until today in the middle of agricultural modernization. It's become an alternative to build sustainable agriculture and institutional support become important element to build it. Related to that, the objective of this research was to analysis how is an agriculture sustainability will be built supported by sustainable institutions in organic agriculture system. The study is a sociological research which assumed itself into constructivist paradigm, which is a qualitative exploration, with specific cases using multi-method. The research was held on October 2008 until February 2009 and located in Ciburuy Village with paddy peasant community as the unit of analysis. The result of the research shows that organic agriculture system in Ciburuy Village is healty rice agriculture system which produce SAE branded rice (Healthy, Save, and Delicious). Technically, the system has not yet became pure organic agriculture which free of synthetic chemical because the using of chemical fertilizer. Nevertheless, a process and also an implementation of the system related to the principles of organic agriculture system. So that, production techniques, social relationships, and the rules that embedded in were built to build agriculture sustainability. With the development of healthy rice farming systems, do not change a working relationship system of division of labor and wage system between tenant farmers and farm laborers. Similarly at harvest activity. The differences appear in the presence of mechanisms that shape institutional providers of fertilizer and pesticides, institutional Cooperative Farmers Group "Lisung Kiwari", institutional post-harvest, and institutional distribution of rice SAE as a product of healthy rice.
\end{abstract}

Keywords : organic agriculture system, institutions sustainability, sustainable agriculture, people center development

\section{PENDAHULUAN}

\section{Latar Belakang}

Pertanian organik masih terus berkembang dan bertahan hingga saat ini di tengah gempuran modernisasi pertanian melalui revolusi hijau. Merujuk sejarah perkembangannya, pertanian organik ini muncul seiring merebaknya isu pembangunan berkelanjutan yang hingga saat ini pula menjadi perhatian masyarakat di seluruh dunia. Konsep pembangunan berkelanjutan pertama kali muncul tahun 1987 dalam sidang WCED (World Commission on Environment and Development). Pada waktu itu, Mrs. G.H. Bruntland (Perdana Menteri Swedia) menyampaikan laporan dengan judul Our Common Future (Hari Depan Kita Bersama). Dalam laporan inilah disebutkan pentingnya pembangunan berkelanjutan (sustainable development), yaitu pembangunan yang berusaha memenuhi kebutuhan generasi masa kini tanpa harus mengorbankan kebutuhan dan aspirasi generasi mendatang (Eicher, 1998; Bahar, 2007). Merujuk pada Eicher (1998), istilah keberlanjutan pertama kali berkembang pada tahun 1980 oleh International Union for the Conservation of Nature and National Resources. Pada pertengahan tahun 1980, konsep keberlanjutan telah mendapat perhatian yang lebih besar sebagai kritik atas pendekatan industrial pada proses pembangunan pertanian. Adapun pertanian organik juga muncul sebagai salah satu implementasi dari pembangunan berkelanjutan tersebut (Sutanto, 2002).

Pertanian organik terus berkembang secara signifikan baik di tingkat dunia, tingkat nasional, maupun tingkat lokal yang tampak dengan semakin bertambahnya luas lahan penanaman dan juga pertumbuhan pasar produk organik tersebut. Tercatat sampai tahun 2003, total luas lahan yang dikelola secara organik di dunia adalah 24 juta hektar. Total penjualan produk organik di seluruh dunia mencapai US\$ 23 miliar. Pasar produk organik utama dunia yaitu di Amerika Serikat dan Kanada juga semakin besar hingga mencapai 51 persen atau US\$ 11 miliar, disusul Eropa sebesar US\$ 10 miliar (46 persen), kemudian Jepang sebesar US\$ 350 juta. Pertumbuhan pasar produk organik diperkirakan mencapai 20-30 persen per tahun. Bahkan di beberapa negara tertentu mencapai 50 persen per tahun. Kenaikan nilai penjualan produk organik ini dipicu oleh harga premium dan tingkat kesadaran konsumen tentang mutu produk. Di Indonesia, produk pangan organik banyak diminati konsumen. Konsumen produk organik telah mencapai 10 persen dari jumlah penduduk. Pencapaian itu dirasa 
membanggakan di tengah gempuran produk kimia yang merajai pasaran saat ini. ${ }^{1}$

Demikian halnya dukungan pemerintah dalam pengembangan pertanian organik. Pada tahun 2001, pemerintah Indonesia melalui Departemen Pertanian telah melakukan serangkaian tahapan sosialisasi mengenai pertanian organik kepada masyarakat ${ }^{2}$. Untuk memajukan pertanian organik, Departemen Pertanian menempatkan perencanaan dan implementasi pertanian organik sebagai salah satu kebijakan pemerintah dalam program pembangunan pertanian di Indonesia. Kebijakan pemerintah tersebut ditujukan untuk menumbuhkan, memfasilitasi, mengarahkan dan mengatur perkembangan pertanian organik melalui adanya sinergisme aktivitas dan pelaku usaha yang dapat mempercepat pencapaian tujuan dari slogan "Go Organic 2010" yaitu menjadikan "Indonesia sebagai salah satu produsen pangan organik utama dunia". Pertanian organik dirancang pengembangannya dalam enam tahapan mulai dari tahun 2001 hingga tahun 2010 (Gambar 1). pertanian modern menjadi sistem pertanian organik (Wangsit, 2003; Kartini, 2005).

Seiring perkembangan tersebut, kini tidak hanya pihak pemerintah, lembaga-lembaga swadaya masyarakat dan petani saja yang bergerak dalam pertanian organik. Kini berdiri pula lebih dari 117 perusahaan yang menangkap adanya peluang usaha dalam pertanian organik ${ }^{3}$. Bisnis usaha komoditi organik pun menjadi trend. Hal ini tidak terlepas dengan adanya potensi permintaan produk organik yang sebanding dengan kesadaran konsumen terhadap pangan yang sehat dan alami ${ }^{4}$. Sehubungan dengan itu, dengan respon yang semakin besar dari para pelaku pertanian maka sistem pertanian organik pun semakin berkembang hingga saat ini baik di tingkat global maupun konteks lokal.

Merujuk pada Rattan dalam Eicher (1998), salah satu permasalahan yang terkait dengan upayaupaya mewujudkan pembangunan pertanian yang berkelanjutan adalah pentingnya dukungan kelembagaan yang sesuai diantara rumah tangga para individu, perusahaan swasta dan organisasi publik yang mencakup pemerintah daerah juga lembaga-lembaga swadaya masyarakat.

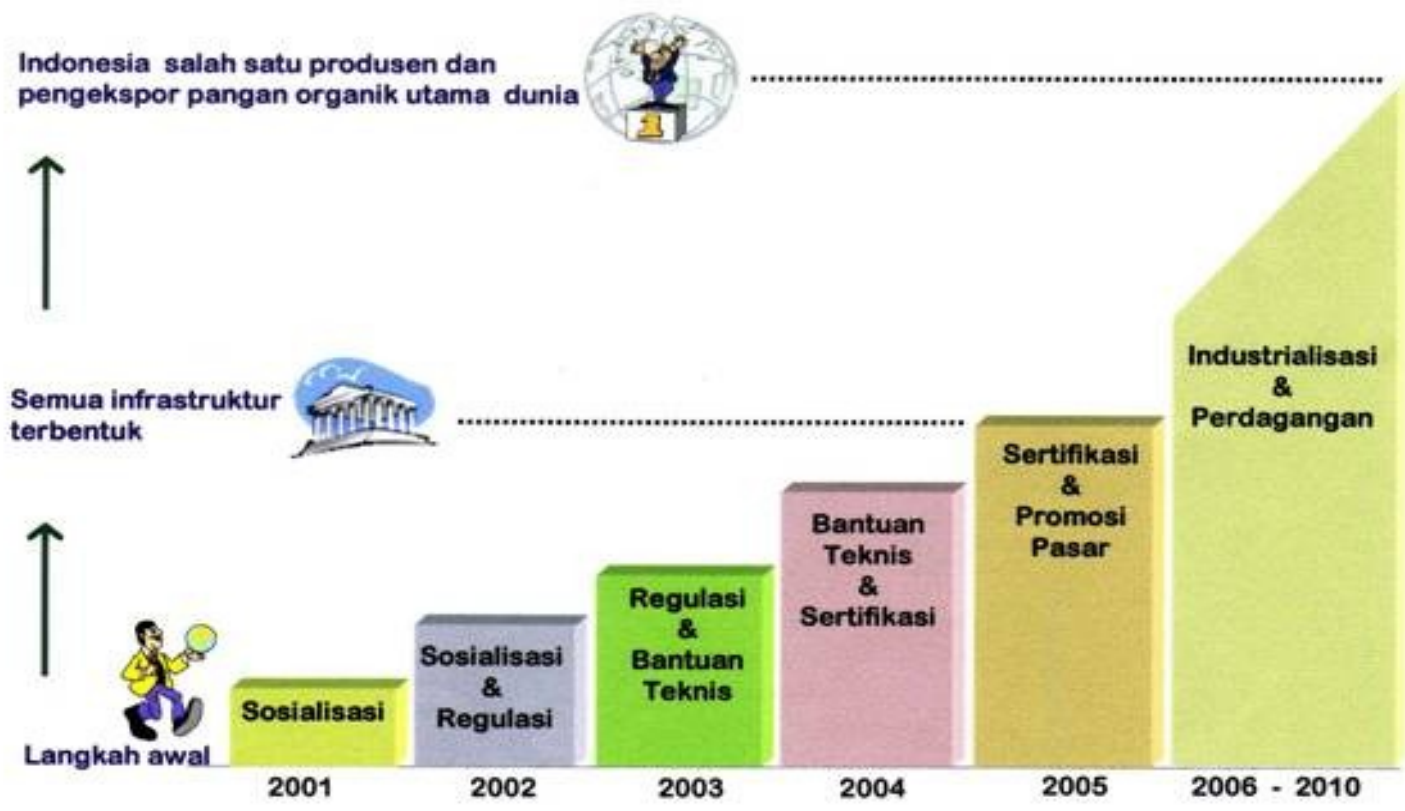

Sumber: Departemen Pertanian, 2005

Gambar 1. Tahapan Pengembangan Pertanian Organik pada Go Organik 2010

Adapun pertanian organik yang dilakukan oleh petani-petani di Indonesia mulai berkembang di tahun 1999 dengan diinisiasi oleh berbagai lembaga swadaya (LSM). Masyarakat petani di beberapa pedesaan di Indonesia khususnya di Jawa sudah merubah sistem pertanian mereka dari sistem

\footnotetext{
${ }^{1}$ Very Herdiman. Berjuang Memperkenalkan Makanan Organik. Jurnal Nasional, Minggu, 27 April 2008.

${ }^{2}$ Dede Sulaeman. Perkembangan Pertanian Organik di Indonesia.

http://agribisnis.deptan.go.id/index.php?files=Berita_Det ail\&id=344
}

Oleh karena itu, dalam kaitannya sistem pertanian organik sebagai upaya untuk mewujudkan pembangunan pertanian yang berkelanjutan, maka dari uraian di atas memunculkan pertanyaan utama bagaimanakah pertanian berkelanjutan dapat diwujudkan melalui keberlanjutan kelembagaan dalam sistem pertanian organik?

\footnotetext{
${ }^{3}$ Direktori Pertanian Organik.

http://agribisnis.deptan.go.id/Pustaka/Bab2-03direktori\%zotaniorganik.pdf

${ }^{4}$ Wacana Organis, Edisi No. 5/Th2 (Desember 2003 Februari 2004)
} 
Dukungan kelembagaan dalam hal ini dititikberatkan pada mekanisme pengaturan (rules of the game) baik dari dimensi yang bersifat regulatif (peraturan perundang-undangan), bersifat normatif (kesepakatan-kesepakatan), maupun bersifat pengetahuan budaya lokal masyarakat (Scott, 2008). Kajian mengenai kelembagaan dari perspektif sosiologis dalam sistem pertanian organik belum banyak dilakukan. Pada beberapa penelitian terdahulu, lebih difokuskan pada tipe-tipe petani yang memilih untuk berubah ke pertanian organik dan tingkat rasionalitas mereka (Darnhofer, 2005), kajian preferensi produk organik (Rusma, 2005), motivasi petani dalam menerapkan usahatani organik (Lauwere, 2005; Rukka, 2003), transformasi struktural dan ideologi dari organisasi-organisasi tingkat nasional (Lockie, 2005), dan berbagai analisis keragaan usahatani berbagai produk organik. Hasil penelitian Suhirmanto (2003) menunjukkan bahwa berubahnya sistem pertanian dari sistem pertanian tradisional menjadi sistem pertanian modern berdampak pada melemahnya kelembagaan tradisi baik pada bidang kegiatan produksi maupun non-produksi. Adapun dari hasil penelitian Radandima (2003), diketahi bahwa pertanian modern melalui adanya pembangunan irigasi menyebabkan terjadinya perubahan pada kelembagaan penguasaan lahan dan kelembagaan hubungan kerja pertanian. Merujuk pada Hayami dan Kikuchi (1987), Ropke (1986), dan Kano (1980) terdapat berbagai bentuk kelembagaan pertanian seperti misalnya kelembagaan-kelembagaan dalam proses intensifikasi pertanian dan kelembagaan panen. Namun, berbagai perubahan kelembagaan tersebut pada intinya didorong oleh karena berubahnya kebutuhan masyarakat sehingga merubah pula mekanisme pengaturan pemenuhan kebutuhan tersebut. Demikian pula halnya, dengan adanya perubahan dalam sistem pertanian menjadi sistem pertanian organik saat ini. Berbagai manfaat diterapkannya sistem pertanian organik baik manfaat dari segi ekonomi, ekologi, dan sosial memunculkan berbagai mekanisme pengaturan baik dari aspek produksi di tingkat petani hingga distribusi produk organik ke tangan konsumen tersebut dan juga aspek kebijakan ditingkat pemerintah. Sehubungan dengan itu, kajian mengenai kelembagaan dalam sistem pertanian organik itu sendiri sangat menarik untuk dikaji lebih lanjut. Sehubungan itu, untuk memperoleh gambaran komprehensif mengenai sistem pertanian organik tersebut, maka rumusan permasalahan penelitian yang akan dikaji adalah :

(1) bagaimanakah bentuk-bentuk kelembagaan yang terdapat dalam sistem pertanian organik ditinjau dari pilar penopang yang membangun kelembagaan tersebut?

(2) Pilar-pilar apa sajakah yang mempengaruhi kelembagaan dalam pertanian organik tersebut?

\section{Tujuan Penelitian}

Tujuan utama penelitian ini adalah untuk mendapatkan pemahaman yang utuh dan menyeluruh mengenai perwujudan keberlanjutan kelembagaan dalam sistem pertanian organik sebagai interpretasi dari tercapainya pembangunan pertanian yang berkelanjutan. Adapun uraian tujuan spesifik dari penelitian ini yaitu :

(1) menganalisis bentuk-bentuk kelembagaan yang terdapat dalam sistem pertanian organik ditinjau dari pilar penopang yang membangun kelembagaan tersebut,

(2) menganalisis pilar-pilar yang membangun kelembagaan dalam pertanian organik.

\section{METODE PENELITIAN}

Pemilihan lokasi penelitian ditentukan secara purposif yakni pada komunitas petani padi sawah di Kampung Ciburuy, Desa Ciburuy, Kecamatan Cigombong, Kabupaten Bogor, Provinsi Jawa Barat. Penentuan lokasi tersebut dilakukan dengan pertimbangan bahwa komunitas tersebut secara bertahap sudah mulai menerapkan sistem pertanian organik dalam menanam padi sejak tahun 2002. Seiring dengan itu, proses ini terus berjalan hingga pada tahun 2004 Lembaga Pertanian Sehat (LPS) Yayasan Dompet Dhuafa Republika mendukung pengembangan pertanian organik khususnya produksi padi sehat melalui Program Pemberdayaan Pertanian Sehat ${ }^{5}$ dan memberi jaminan pasar beras sehat tersebut. Kerjasama yang dibangun antara kelompok tani, koperasi, dan LPS ini mampu menciptakan sebuah produk unggulan. Produk unggulan komunitas petani setempat adalah beras SAE (Sehat, Aman, Enak). Program tersebut berkembang hingga saat ini beras sehat dari Kampung Ciburuy ini sudah memiliki jaringan distribusi yang relatif tetap. Keberhasilan program tersebut juga tidak terlepas dari adanya peran Koperasi Kelompok Tani "Lisung Kiwari". Secara konsisten, komunitas ini terus secara bertahap mengembangkan praktek budidaya padi dengan mengacu pada standar organik ${ }^{6}$. Pada tahun 2006, Desa Ciburuy ini menjadi salah satu lokasi penerapan program pengembangan pertanian organik untuk komoditi padi yang pertama kali disosialisasikan di Kabupaten Bogor. Oleh karena itu, lokasi ini seringkali menjadi salah satu rujukan utama tempat penelitian dan pelatihan pertanian organik di Kabupaten Bogor ini. Penelitian dilaksanakan dari bulan Oktober 2008 sampai dengan Februari 2009. Pemilihan unit analisis

\footnotetext{
5 Program LPS dengan memberikan bantuan biaya sewa lahan kepada kelompok tani yang anggotanya tergolong mustahik (penerima zakat). Anggota kelompok ini juga menjadi anggota koperasi kelompok tani "Lisung Kiwari". Adapun kewajiban setiap anggota kelompok adalah pada setiap kali panen dari lahan yang sudah disewa tersebut, dari 1 kuintal beras harus ditabungkan ke koperasi sebanyak $4 \mathrm{~kg}$ untuk biaya panen tahun berikutnya.

${ }^{6}$ bebas residu pestisida
} 
didasarkan pada persoalan yang hendak diteliti. Untuk mengkaji kelembagaan, maka subyek penelitian yang dipilih adalah individu petani sebagai bagian dari komunitas petani padi sawah di Kampung Ciburuy, serta para individu sebagai pihak-pihak yang terlibat dalam berbagai kelembagaan yang terbentuk dalam sistem pertanian organik tersebut. Penelitian ini menggunakan paradigma konstruktivis, dimana melalui penelitian ini peneliti berupaya untuk memahami dan membentuk kembali konstruksi tentang suatu realitas sosial, dengan tujuan untuk mengarahkan konsensus namun tetap terbuka terhadap interprestasi baru sebagai informasi dan peningkatan kesempurnaan. verifikasi kesimpulan (Miles dan Haberman sebagaimana dikutip oleh Sitorus, 1998).

\section{PEMBAHASAN}

Desa Ciburuy secara administratif merupakan salah satu desa yang berada di Kecamatan Cigombong, Kabupaten Bogor, Propinsi Jawa Barat. Desa Ciburuy memiliki luas wilayah $160 \mathrm{Ha}$. Luasan tersebut dipergunakan untuk tanah sawah seluas 80 Ha. Kampung Ciburuy merupakan areal penanaman padi sawah yang terbesar di Desa Ciburuy.

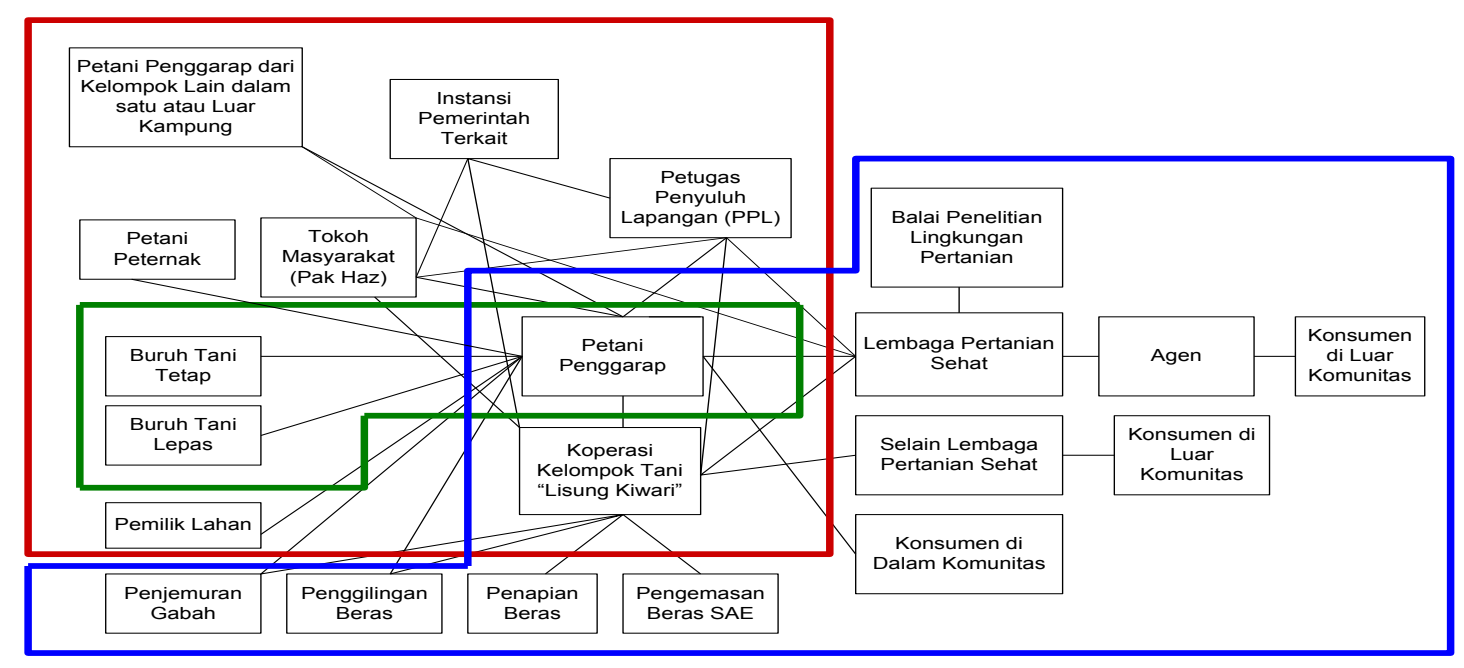

Keterangan :

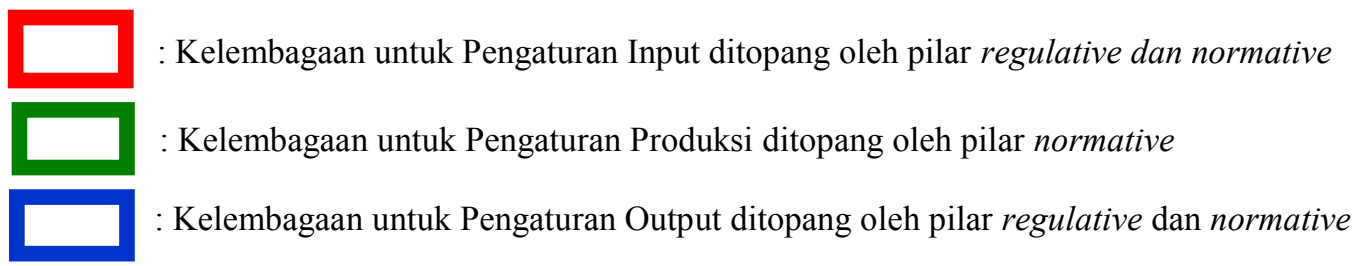

Gambar 1. Bentuk dan Pilar Kelembagaan dalam Sistem Pertanian Padi Sehat di Kampung Ciburuy, Kecamatan Cigombong, Kabupaten Bogor

Berkaitan dengan pilihan paradigma di atas, maka penelitian ini menggunakan pendekatan kualitatif dan strategi penelitian yang digunakan adalah studi kasus. Penulis menggunakan beberapa teknik pengumpulan data yaitu wawancara mendalam dengan panduan pertanyaan, pengamatan berperanserta, dan kajian literatur. Analisis data kualitatif dilakukan oleh penulis sebagai proses yang berlanjut, berulang, dan terus-menerus sehingga dalam waktu yang bersamaan dengan proses pengumpulan data di lapangan.. Penelitian bergerak diantara empat sumbu yaitu pengumpulan data, reduksi data, penyajian data, dan penarikan atau
Oleh karena itu, bekerja di bidang pertanian adalah mata pencaharian yang dominan bagi sebagian besar penduduk di kampung ini. Kampung Ciburuy menjadi salah satu pusat pengembangan sistem pertanian organik di Kabupaten Bogor sejak tahun 2006 melalui pengembangan sistem pertanian padi sehat. Padi merupakan salah satu komoditas unggulan bagi komunitas petani di Kampung Ciburuy, Desa Ciburuy ini. Komunitas petani di Kampung ini memiliki produk unggulan yang mampu memenuhi selera pasar saat ini. Produk beras yang dihasilkan komunitas petani di Kampung 
Ciburuy adalah beras SAE yaitu beras Sehat, Aman, dan Enak.

Beras ini secara berkala (setiap 6 bulan) di uji di laboratorium residu bahan agrokimia pada Balai Penelitian Lingkungan Pertanian di Jalan Laladon-Ciomas, Bogor. Beras tersebut dihasilkan dari suatu sistem pertanian yang disebut dengan sistem pertanian padi sehat.

Sistem pertanian padi sehat di Kampung Ciburuy ini dapat diindentifikasi dari beberapa bentuk kelembagaan. Kelembagan-kelembagaan tersebut terbentuk dengan adanya hubunganhubungan antar petani (dalam status yang sama maupun berbeda), petani dengan kelompok tani, petani sebagai individu maupun sebagai kelompok dengan lembaga koperasi setempat, dan lembaga koperasi dengan lembaga pertanian sehat. Beberapa bentuk kelembagaan tersebut adalah kelembagaan untuk pengaturan input, kelembagaan untuk pengaturan produksi, dan kelembagaan untuk pengaturan output (Gambar 1). Kelembagaan untuk pengaturan input mencakup kelembagaan koperasi, kelembagaan penyediaan pupuk dan pestisida, kelembagaan untuk penyediaan kredit, kelembagaan penguasaan lahan, dan kelembagaan untuk penyebarluasan inovasi dan teknologi yang mencakup kelembagaan kelompok tani dan kelembagaan penyuluhan. Kelembagaan untuk pengaturan produksi mencakup kelembagaan hubungan kerja dan kelembagaan panen. adapun kelembagaan untuk pengaturan output meliputi kelembagaan pasca panen dan kelembagaan distribusi.

\section{Kelembagaan untuk Pengaturan Input Kelembagaan Koperasi}

Koperasi sebagai lembaga ekonomi berbadan hukum adalah soko guru perekonomian masyarakat Indonesia khususnya. Demikian pula halnya dengan keberadaan Koperasi Kelompok Tani Lisung Kiwari ditengah-tengah komunitas petani padi sawah di Kampung Ciburuy. Lembaga yang berdiri dengan akta pendirian koperasi nomor 518/03/BH/KPTS/Kankop/2005 ini, harus menjalankan segala bentuk usaha dengan merujuk pada hak dan kewajiban hukum yang tercantum dalam Undang-Undang Republik Indonesia Nomor 25 Tahun 1992 tentang Perkoperasian.

Berkembangnya koperasi kelompok tani Lisung Kiwari ini tidak terlepas dari peranan Pak Haz selaku tokoh masyarakat dan Pak Edd selaku penyuluh pertanian setempat. Kolaborasi kedua tokoh tersebut telah memberi pembinaan secara intensif dan komprehensif sejak proses awal pembentukan koperasi kelompok tani tahun 2004 lalu. Selain itu, keberhasilan koperasi tersebut juga berkat peranan Kang $\mathrm{Hk}$ selaku ketua koperasi. Dalam posisinya selaku anak dari tokoh masyarakat terkemuka, Kang Hk berhasil menunjukkan kualitas dirinya dalam mengelola koperasi baik dalam pengelolaan keuangan maupun pengembangan jejaring kerjasama bersama mitra-mitra koperasi kelompok tani Lisung Kiwari. Selain itu, Kang HK juga menerapkan beberapa program komputer khusus dalam mekanisme penjualan dan pembelian barang di koperasi. Sistem komputerisasi ini sangat mendukung kinerja koperasi untuk menghasilkan data terperinci pengelolaan koperasi sehari-hari.

Dari hasil penelitian diketahui bahwa koperasi kelompok tani Lisung Kiwari berperan penting dalam sistem pertanian padi sehat di Kampung Ciburuy baik dalam sistem produksi maupun sistem distribusi. Aktivitas input, produksi, maupun output terkait dengan peran dan fungsi koperasi setempat sebagai lembaga lokal pendukung pembangunan pertanian. Di samping sebagai penyedia input pertanian, Koperasi kelompok tani Lisung Kiwari juga menjadi lembaga penyedia modal (dalam bentuk pinjaman uang tunai) khususnya untuk menunjang aktivitas pertanian para petani padi setempat. Untuk menunjang aktivitas output, koperasi ini menjadi lembaga yang menjembatani komunitas petani padi dengan lembaga pertanian sehat dan mitra lainnya untuk memperluas segmen distribusi padi sehat yang diproduksi oleh petani padi di Kampung Ciburuy.

Para petani di Kampung Ciburuy dapat dengan mudah memperoleh pinjaman kredit usahatani dari Koperasi Kelompok Tani Lisung Kiwari. Koperasi tersebut memiliki modal dari iuran dan tabungan para anggotanya serta dana-dana bantuan dari pemerintah seperti halnya Dewan Pembinaan Modal Lembaga Usaha Ekonomi Pedesaan (DPM LUEP). Proses pengucuran dana bantuan tersebut harus melalui prosedur yang didasarkan atas hukum dan ketentuan berlaku yang dibentuk antara koperasi kelompok tani Lisung Kiwari dengan pemerintah (melalui dinas pertanian setempat). Koperasi memiliki kemudahan untuk mengakses sumber dana dari pemerintah oleh karena menjadi lembaga yang berbadan hukum dengan mekanisme usaha yang jelas sehingga penggunaan dana pun dapat dipertanggungjawabkan dengan baik.

Proses pemberian pinjaman dari koperasi kepada para petani pun dilakukan dengan mudah dan cepat. Proses peminjaman pun dilakukan atas dasar ketentuan-ketentuan yang berlaku di koperasi, seperti ketentuan bunga sebesar 20 persen dari besarnya pinjaman, dan ketentuan besarnya pinjaman tergantung dari besarnya tabungan atau kedisiplinan membayar iuran wajib dan pokok anggota ke koperasi. Menurut Kang Hk selaku ketua koperasi, kedisiplinan dalam membayar iuran dan pembayaran hutang menjadi indikator kepada para anggota untuk mendapatkan pinjaman selanjutnya. Bagi petani yang pernah melakukan ketidakdisiplinan pembayaran iuran atau pembayaran hutang dinilai sudah merusak kepercayaan dan sulit memperoleh hutang selanjutnya. Dari sisi petani, pemberian kredit dari koperasi sangat memberi kemudahan karena tidak berbelit-belit, tanpa agunan pun tidak masalah. Saling menjaga kepercayaan menjadi hal pokok dan 
berjalannya sistem "yarnen" atau hutang dibayar apabila panen turut melandasi kemudahan proses pemberian kredit tersebut.

Hasil temuan lapang menunjukkan tidak semua anggota kelompok tani menjadi anggota koperasi. Namun, semua ketua kelompok tani menjadi anggota koperasi. Hal ini dikarenakan bagi sebagian petani iuran pokok dan iuran wajib dirasakan memberatkan atau sebagian petani masih belum memahami manfaat positif berkoperasi. Bagi petani yang belum masuk menjadi anggota koperasi dapat mewakilkan peminjaman kredit mereka kepada ketua kelompok tani. Jadi peminjaman kredit dilakukan antara ketua kelompok tani dengan ketua koperasi. Ketua kelompoklah yang turut menjamin kepercayaan dalam proses pemberian kredit tersebut. Kredit yang diberikan tidak hanya berupa uang, tapi juga berupa sarana produksi.

Koperasi sebagai lembaga yang berkekuatan hukum memiliki kemudahan untuk mengakses program-program pemerintah khususnya yang terkait dengan permodalan sebagaimana halnya program LUEP. Dari perguliran dana LUEP ini, diperoleh keuntungan koperasi senilai Rp 3.000.000,- yang akan menjadi sumber penghitungan sisa hasil usaha bagi anggota koperasi. Adanya sumber permodalan ini. Selain itu, koperasi juga mengadakan perjanjian dan kesepakatankesepakatan jual-beli antara lembaga-lembaga mitra dalam sistem distribusi beras SAE.

Menilik proses pembentukannya, koperasi didirikan dengan merujuk tata perundangan yang berlaku. Segala bentuk aktivitas dijalankan dengan merujuk tata aturan tersebut hingga tersusun suatu Anggaran Dasar (AD) dan Anggaran Rumah Tangga (ART) Koperasi Kelompok Tani Lisung Kiwari. Sebagai koperasi kelompok tani, maka salah satu bidang usaha yang dijalankan adalah penyediaan sarana produksi pertanian berupa input seperti benih, pupuk, dan pestisida. Selain itu, koperasi juga memberikan layanan peminjaman uang untuk modal petani menggarap lahan. Selain itu, koperasi juga memberi jaminan pasar kepada para petani. Pada intinya, koperasi berperan penting dalam aktivitas input, aktivitas produksi, dan aktivitas output bagi komunitas petani padi sehat di Kampung Ciburuy. Dari segi tata laksana perkoperasian, sebagai lembaga yang berbadan hukum maka kelembagaan ini tampak ditopang oleh pilar regulatif. Artinya apabila koperasi melaksanakan aktivitas di luar AD/ART yang telah dirumuskan maka akan dikenai sanksi hukum yang berlaku.

\section{Kelembagaan untuk Penyediaan Pupuk dan Pestisida}

Penggunaan pupuk organik merupakan aturan penting dalam budidaya padi sehat. Petani pada umumnya menggunakan kotoran kambing sebagai pupuk organik. Kotoran kambing ini mudah diperoleh oleh karena sebagian besar petani memiliki kambing dengan jumlah berkisar 2 sampai
6 ekor. Untuk memenuhi kebutuhan pemupukan di lahan, para petani biasa memperjualbelikan kotoran kambing yang mereka miliki dengan harga Rp 500,per kilogram. Harga tersebut adalah harga kotoran kambing murni yang belum difermentasikan. Para petani melakukan sendiri proses fermentasi kotoran kambing menjadi pupuk organik dengan menggunakan aktivator EM4.

Selain transaksi jual beli, oleh karena kegiatan pemupukan dilakukan secara bergiliran sesuai dengan jadwal budidaya masing-masing petani, maka para petani melakukan saling meminjamkan kotoran kambing yang dimiliki dan mengembalikan ketika dibutuhkan sesuai besarnya peminjaman. Petani menyebutnya dengan istilah "nyimpen" atau menyimpan dulu. Petani dapat saling meminjamkan baik dengan anggota kelompok maupun di luar kelompok. Petani tidak melakukan pencatatan terkait dengan jumlah peminjaman maupun pengembalian, hanya berpatokan pada waktu pemupukan akan dilakukan oleh petani pemberi pinjaman. Baik pemberi pinjaman maupun si peminjam memiliki rasa saling percaya bahwa pada waktu pemupukan, si peminjam akan mengembalikan pinjaman kotoran kambingnya.

Kondisi ini menunjukkan bahwa komunitas petani setempat dapat memenuhi input khususnya pupuk kandang secara mandiri. Meskipun masih menggunakan pupuk kimia, namun diupayakan untuk digunakan secara minimal. Beberapa cara dilakukan untuk meminimalisasi aplikasi pupuk kimia seperti dengan cara membenamkan jerami pada saat pengolahan lahan atau menjadikan lahan sawah menjadi kolam ikan sebelum masuk masa tanam berikutnya. Proses tersebut dapat meningkatkan kadar urea secara alami dalam tanah. Implikasi lebih lanjut adalah semakin berkurangnya biaya untuk membeli pupuk kimia.

Untuk memenuhi kebutuhan pupuk kimia, para petani di Kampung Ciburuy dapat dengan mudah memperolehnya dari Koperasi Kelompok Tani Lisung Kiwari. Para petani dapat membeli secara langsung atau meminjam dahulu dan membayarnya saat panen. Adapun terkait dengan input pestisida, para petani padi sehat di Kampung Ciburuy sudah tidak menggunakan pestisida kimia di lahan sawahnya. Para petani pada umumnya membuat sendiri pestisida nabati dengan bahanbahan alami yang tersedia di kampung tersebut.

Sebelum sistem pertanian padi sehat berkembang di Kampung Ciburuy, para petani juga dengan mudah memperoleh pestisida kimia dari Koperasi Kelompok Tani Lisung Kiwari. Pihak koperasi harus membeli pestisida kimia tersebut ke toko saprodi di Pasar Bogor, Kota Bogor. Setelah sistem pertanian padi sehat berkembang sejak tahun 2002, maka pihak koperasi menghentikan pembelian pestisida kimia ke Pasar Bogor.

Selain pupuk kimia, koperasi juga menjual benih-benih padi seperti varietas ciherang, bondoyudo, situbagendit, IR 64, hibrida, rojolele, conde, pandan wangi dan cibogo. Koperasi 
memperoleh benih-benih padi tersebut dengan membeli dari toko saprodi di luar Kampung Ciburuy. Dengan membeli input dari koperasi, para petani memperoleh berbagai keuntungan yaitu tidak membutuhkan biaya transport, dapat meminjam dahulu, dan dari keuntungan koperasi, pada akhir tahun para petani memperoleh sisa hasil usaha (SHU).

Input lain yang berperan penting adalah pembajakan. Untuk kebutuhan ini, para petani dapat menggunakan jasa peminjaman traktor atau kerbau. Para petani dapat menyewa traktor Pak Haz atau menyewa kerbau kepada Pak Emd. Pak Haz dan Pak Emd adalah satu-satunya pemilik alat bajak di Kampung Ciburuy. Biaya sewa traktor adalah sebesar Rp 50.000,- yang dibayarkan melalui operator traktor yaitu Pak Jmd. Pak Jmd kemudian membayarkan biaya sewa tersebut kepada Pak Haz sebesar Rp 25.000,-, biaya perawatan Rp 10.000,-, dan uang lelah beliau sebesar Rp 15.000,Sedangkan biaya sewa kerbau adalah Rp 60.000,dan dibayarkan kepada Pka Emd selaku operator bajak yang sekaligus pemilik.

\section{Kelembagaan Penguasaan Lahan}

Akses tanah menjadi salah satu input yang sangat penting dalam bertani. Beberapa kelembagaan penguasaan lahan yang terdapat di Desa Ciburuy meliputi sistem sewa, sistem gadai, hak garap dan sistem maro. Kelembagaan tersebut terbentuk terutama oleh karena sebagian besar lahan di kampung ini adalah milik orang di luar Kampung Ciburuy sehingga petani setempat mayoritas hanya menjadi petani penggarap lahan dan petani penggarap yang juga diberi hak kuasa oleh para pemilik lahan untuk mengelola hasil lahan mereka. Namun, seorang petani memungkinkan untuk terlibat dalam beberapa bentuk kelembagan penguasaan lahan. Sebagaimana halnya Pak Myd (43 tahun), yang menggarap lahan milik Pak Win dan Ibu Hjk dengan sistem maro. Dari setiap hasil panen baik pemilik maupun penggarap memperoleh masing-masing 50 persen dari hasil penjualan dikurangi dengan biaya-biaya produksi. Di samping itu, Pak Myd juga mempunyai lahan gadaian yang kini sedang beliau garap seluas $1000 \mathrm{~m}^{2}$ di luar Kampung Ciburuy. Sistem gadai tersebut terbentuk karena si pemilik lahan meminjam uang kepada Pak Myd. Untuk lahan seluas 1000 meter yang digadaikan, si pemilik memperoleh uang sebesar Rp 2.500.000,-. Lahan tersebut akan kembali ke tangan si pemilik lahan apabila uang Pak Myd sudah dikembalikan. Selama uang tersebut belum dikembalikan, maka hak untuk menggarap lahan berada di tangan Pak Myd. Dengan sistem ini, si pemilik lahan tidak berhak memperoleh bagian dari hasil lahan tersebut.

Demikian pula dalam sistem sewa sebagaimana yang terjadi di lahan Pak Haz. Selain disewa oleh taruna tani untuk kegiatan lapang, sebagian lagi lahan Pak Haz juga disewa oleh Pak Jmd dengan harga sewa yang sama yaitu Rp
3.000 .000 ,- per tahun untuk lahan seluas $3000 \mathrm{~m}^{2}$. Pemilik lahan yang menyewakan lahannya tidak berhak memperoleh bagian dari hasil lahan tersebut. Selain memiliki lahan yang disewakan, Pak Haz juga menggarap lahan milik adik beliau, Ibu Hjt, dengan sistem maro. Setiap panen petani penggarap berhak memperoleh 60 persen dari hasil lahan setelah dikurangi berbagai biaya produksi, sedangkan pemilik lahan berhak memperolah 40 persen.

Berbeda dengan Pak Jum yang memiliki hak garap dari Pak Haz. Selain menggarap lahan Pak Haz, Pak Jum menjadi pekerja tetap di lahan Pak Haz tersebut. Pak Jum menggarap lahan Pak Haz seluas $1000 \mathrm{~m}^{2}$. Seluruh hasil penjualan panen gabah diberikan kepada Pak Jum, dan Pak Haz hanya meminta Pak Jum untuk menabungkan ke koperasi sebanyak 2 kuintal dari berapapun hasil panen yang beliau peroleh.

Penguasaan lahan untuk aktivitas pertanian tidak hanya diperuntukkan bagi aktivitas produksi saja. Terkait dengan status pengunaan lahan, saranasarana penunjang aktivitas produksi pertanian di Kampung Ciburuy secara dominan dimiliki oleh Pak Haz. Seperti halnya saung pertemuan Gapoktan Silih Asih, ruang belajar untuk pelatihan, bangunan koperasi, gudang beras, gudang pupuk, gudang penyimpanan alat dan mesin pertanian semua berada di atas lahan milik Pak Haz. Akan tetapi, secara manajemen, segala bentuk pertanggung jawaban atas pengelolaan aset-aset tersebut ditempatkan atas nama lembaga. Sehubungan dengan itu, lembaga membangun hubungan tersendiri dengan pemilik lahan tersebut secara profesional. Baik Gapoktan Silih Asih, Koperasi Kelompok Tani "Lisung Kiwari”, maupun penggunaan lahan Pak Haz untuk kegiatan sekolah lapang memberi uang sewa kepada Pak Haz sebagai kompensasi dari penggunaan lahan tersebut. Untuk biaya sewa lahan yang dipergunakan saung, ruang belajar, bangunan koperasi, dan gudang-gudang adalah sebesar Rp 1.000.000,- per tahun, sedangkan biaya sewa lahan untuk kegiatan sekolah lapang taruna tani seluas $3000 \mathrm{~m}^{2}$ adalah $\mathrm{Rp}$ 3.000.000,- per tahun. Adapun lahan yang dipergunakan untuk aktivitas penjemuran gabah, pengeringan gabah, penggilingan beras, lokasi pembuatan pupuk organik OFER, dan kompos adalah milik PT. BSS, sehingga koperasi harus menyewa lahan tersebut sebesar Rp 2.500.000,- per tahun.

Dari uraian yang telah dikemukakan menunjukkan bahwa kelembagaan penguasaan lahan didukung oleh pilar normatif. Hubungan antara pemilik lahan dan petani penggarap dilakukan atas dasar kepercayaan dan komitmen yang ditelah dibangun. Kedua pihak berkepentingan untuk memperoleh keuntungan ekonomi dari lahan garapan. Pemilik lahan menguasakan lahannya untuk digarap oleh petani dan petani menggarap lahan tersebut sehingga memberikan hasil yang menguntungkan kedua pihak baik dengan sistem sewa, sistem gadai, hak garap dan sistem maro. Untuk mengelola lahan agar memperoleh 
keuntungan optimal, pemilik lahan harus berjalan sebagaimana sistem atau aturan yang telah disepakati sehingga hubungan ini terus berlanjut. Sebagaimana halnya hubungan antara Pak Win dan Pak Myd, Pak Jum dan Pak Haz, Pak Haz, dan PT. BSS. Apabila salah satu pihak melanggar komitmenkomitmen yang telah disepakati tersebut, maka akan merusak hubungan tersebut akibat hilangnya kepercayaan dari pihak-pihak terkait. Seperti kasus yang terjadi antara Pak Win (pemilik lahan yang digarap oleh Pak Myd). Sebelum Pak Win menguasakan lahan kepada Pak Myd, beliau menguasakan lahan seluas 2,5 hektar miliknya kepada Pak Why. Pak Myd hanya bertanggung jawab kepada Pak Why dan bukan berhubungan langsung dengan Pak Win. Namun, Pak Why berlaku tidak jujur dalam pelaporan hasil lahan, sehingga Pak Win merasa dirugikan. Oleh karena itu, kerjasama antara Pak Why dan Pak Win tidak berlanjut dan Pak Win kemudian memberi kuasa pengelolaan lahannya kepada Pak Myd. Bagi Pak Myd sendiri adalah suatu penghargaan tersendiri hingga saat ini beliau mampu mempertahankan hubungannya dengan pemilik lahan. Meskipun kesepakatan-kesepakatan dalam mekanisme pengelolaan dan pelaporan hasil lahan tidak dilakukan secara tertulis, namun selama 13 tahun hubungan ini berjalan dapat memenuhi kepentingan kedua belah pihak.

\section{Kelembagaan Kelompok Tani}

Sistem pertanian padi sehat di Kampung Ciburuy melibatkan hubungan-hubungan antara petani padi setempat yang tampak melalui pembentukan kelompok tani. Saat ini di Kampung Ciburuy terdapat 6 kelompok tani yaitu kelompok tani Tunas Inti, Saung Kuring, Lisung Kiwari, Silih Asih I, Silih Asih II, dan Manunggal Jaya. Jadi, total petani padi yang menjadi anggota kelompok tani berjumlah 168 orang.

Pada dasarnya sejak tahun 1979, pembentukan kelompok tani di Kampung Ciburuy ini sudah dirintis oleh Pak Haz. Namun, baru pada tahun 2004 kelompok-kelompok tani di Kampung Ciburuy ini mulai lebih terbina. Kelompokkelompok tani tersebut kemudian tergabung dalam Gabungan Kelompok Tani (Gapoktan) Silih Asih yang diketuai oleh Pak Haz. Pada tahun tersebut, Gapoktan Silih Asih membuat perjanjian kerjasama jual beli beras dengan Lembaga Pertanian Sehat (LPS) Yayasan Domper Dhuafa Republika. Pihak LPS menyetujui untuk memberikan jaminan pasar dengan menampung beras hasil panen para petani anggota Gapoktan Silih Asih. Adapun pihak Gapoktan Silih Asih menyetujui untuk memberikan jaminan ketersediaan produk beras dengan volume 8 - 10 ton per bulannya. Beras yang diperjualbelikan harus dihasilkan dari budidaya padi tanpa menggunakan pestisida kimia atau disebut dengan padi sehat. Jadi para petani anggota Gapoktan Silih Asih dituntut untuk membudidayakan padi sehat yang bebas pestisida kimia tersebut.
Berdasarkan aturan tersebut maka kelembagaan kelompok tani di Kampung Ciburuy masih tetap berjalan hingga saat ini. Pilar normatif tampak menopang kelembagaan tersebut. Hal ini ditunjukkan dengan adanya kesepakatan antara kedua pihak untuk mendefinisikan pentingnya membudidayakan padi sehat dan pentingnya jaminan pasar serta jaminan ketersediaan produk dalam menunjang sistem pertanian organik. Sehubungan dengan itu, kedua pihak merancang langkah-langkah yang tepat guna mencapai tujuan tersebut. Kedua pihak merumuskan tata aturan kerja dalam proses produksi hingga pasca panen, menentukan mekanisme pengiriman barang dan sistem pembayaran. Adapun permasalahan-permasalahan yang muncul kemudian dari mekanisme perjanjian tersebut diselesaikan secara kekeluargan dengan menekankan rasa saling pengertian antara kedua pihak. Meskipun keduanya adalah lembaga yang berbadan hukum, namun sanksi secara moral lebih tampak karena dasar-dasar kepatuhan yang melandasi adalah komitmen dan kepercayaan.

Dalam konteks internal, hubungan antara petani ini lebih pada bentuk pertukaran informasi dan pengalaman dalam penerapan sistem produksi. Dari hasil pengamatan lapang, para petani setempat memiliki karakteristik yang berbeda. Namun, pada dasarnya tidak mudah merubah kebiasaan petani setempat. Terkait dengan hal itu, baik Pak Haz maupun Pak Edd selaku penyuluh, mengemukakan bahwa tidak mudah merubah kebiasaan petani tapi bukan tidak mungkin petani tersebut mau untuk berubah kearah yang lebih baik dan menguntungkan. Salah satunya terletak pada kualitas hubungan antara petani setempat dan ini terkait dengan motivasi para petani setempat untuk bergabung menjadi anggota kelompok tani.

Motivasi petani untuk menjadi anggota kelompok tani adalah untuk kemudahan informasi dan aktivitas seputar pertanian, saling bertukar pengalaman, dan ajang silaturahmi antar petani setempat. Namun, motivasi tersebut tidak terlepas dari peran dan fungsi ketua kelompok dalam mendampingi anggotanya sebagaimana yang dikemukakan oleh Pak Pei. Pada umumnya ketua kelompok adalah orang yang paling dipercaya dan disegani karena memiliki tingkat pengetahuan dan pengalaman yang lebih tinggi dibandingkan anggota kelompok. Selain itu, para ketua kelompok memiliki kemauan untuk mencoba informasi berupa inovasi ${ }^{7}$ dan teknologi baru seperti halnya terkait dengan pertanian organik. Mereka seringkali bersedia untuk

\footnotetext{
${ }^{7}$ Sesuatu ide, perilaku, produk, informasi, dan praktikpraktik baru yang belum banyak diketahui, diterima, dan digunakan atau dilaksanakan oleh sekelompok warga masyarakat dalam satu lokalitas tertentu untuk melakukan perubahan tertentu di bidang ekonomi, politik, dan sosial budaya demi tercapainya perbaikan mutu hidup seluruh masyarakat yang bersangkutan (Mardikanto, 1988)
} 
menjadikan lahan garapan mereka sebagai media demonstrasi plot teknologi baru.

Dari hasil penelitian, diketahui bahwa keenam ketua kelompok tani yang menjadi anggota Gapoktan Silih Asih tersebut memiliki intensitas interaksi yang cukup tinggi dengan Pak Haz selaku ketua gapoktan dan Pak Edd selaku penyuluh pertanian setempat. Terlebih oleh karena sebagian besar ketua kelompok memiliki hubungan yang erat dengan Pak Haz. Pak Jy dan Pak Jum adalah pekerja tetap di lahan garapan Pak Haz, Pak Ipg adalah adik kandung Pak Haz, dan Pak Suk adalah pekerja pembuat pupuk organic OFER (Organic Fertilizer) yang bekerja pada Kang Hk (anak Pak Haz yang juga menjadi ketua koperasi). Lokasi rumah mereka pun sangat berdekatan. Oleh karena itu, adanya dukungan kedekatan secara territorial menjadi faktor utama terselenggaranya pertemuan rutin dan memberi kemudahan pada proses persebaran informasi inovasi dan teknologi baru termasuk pertanian organik. Saung Gapoktan Silih Asih dan Ruang Belajar P4S yang terletak di Kampung Ciburuy tersebut adalah tempat dimana pertemuan antara anggota kelompok tersebut berlangsung secara rutin.

Kelembagaan kelompok tani merupakan perwujudan dari adanya kelembagaan penyuluhan. Terkait dengan peranan penyuluh di Kampung Ciburuy, para petani menilai bahwa penyuluh berperan penting dalam memberikan informasi teknologi baru. Terlebih sosok Pak Edd penyuluh pertanian setempat. Secara struktural, Pak Edd adalah penyuluh pertanian tanaman pangan dengan status PNS yang menjalankan peran dan fungsi merujuk pada tata perundang-undangan ${ }^{8}$. Pak Edd tidak hanya dituntut untuk melakukan kegiatan penyuluhan menurut program dan programa yang direncanakan di tingkat pemerintah, namun juga dituntut untuk menyusun program dan program penyuluhan yang memadukan aspirasi petani dan masyarakat pertanian dengan potensi wilayah binaannya.

Seperti halnya di Kampung Ciburuy, selain mengetahui tentang budidaya padi, juga memahami sistem pertanian padi sehat didalamnya, termasuk pengembangan kelompok tani dan pengembangan koperasi. Selain itu, beliau selalu mendampingi Pak Haz apabila Gapoktan Silih Asih mendapat kunjungan para tamu baik dari Dinas Kabupaten dan kecamatan, penyelenggaraan pelatihan pertanian, dan lembaga-lembaga mitra. Perkembangan pertanian organik di Kampung Ciburuy tidak terlepas dari peran Pak Edd. Dalam menerapkan metode penyuluhan, Pak Edd adalah penyuluh yang professional, sangat berdedikasi dalam menjalankan profesinya, sederhana namun kreatif dan memiliki

\footnotetext{
${ }^{8}$ Pusat Penyuluhan Pertanian, 1996, Keputusan Bersama Menteri Dalam Negeri dan Menteri Pertanian Nomor 54 Tahun 1996/301/Kpts/LP.120/4/96, tentang Pedoman Penyelenggaraan Penyuluhan Pertanian dan Petunjuk Pelaksanaannya.
}

kemampuan beradaptasi yang tinggi dengan komunitas petani padi di Kampung Ciburuy. Dalam melakukan pendampingan, Pak Edd mampu menerapkan kombinasi metode sehingga secara bertahap dapat mencapai tujuan penyuluhan.

Sebagai sosok yang merepresentasikan unsur pemerintah, Pak Edd tidak hanya menjalankan proyek dan program pemerintah yang ditugaskan pada beliau untuk disampaikan pada komunitas petani binaannya. Sebagaimana contoh ketika beliau dilibatkan dalam proyek pengadaan ruang belajar pelatihan pertanian. Pak Edd membuatkan proposal pengajuan dana ke instansi terkait untuk membangun ruang belajar tersebut. Lebih lanjut, dana yang diperoleh dikelola oleh Pak Haz hingga kini di Kampung Ciburuy terdapat ruang belajar pusat pelatihan pertanian pedesaan Gapoktan Silih).

Di samping itu, beliau juga mendampingi kelompok tani pangan di Kampung Ciburuy untuk merealisasikan penerapan fungsi manajer pengendali mutu yang digagas oleh Pak Haz. Bersama Pak Haz dan para ketua kelompok yang diberi tanggung jawab sebagai manajer pengendali mutu, Pak Edd melakukan pertemuan rutin setiap minggunya yang dilaksanakan di ruang belajar pusat pelatihan pertanian pedesaan atau di saung pertemuan Gapoktan Silih Asih (Lampiran 8, Foto 3, 4). Pertemuan tersebut juga dihadiri oleh dua orang anggota kelompok tani dari luar Kampung Ciburuy yaitu Pak Kmr dari kelompok tani Dukuh Jaya, Desa Cisaladah dan Pak Hnd dari kelompok tani Harapan Maju, Desa Pasir Jaya. Pertemuan yang diselenggarakan setiap hari kamis ${ }^{9}$ pukul 14.0017.00 tersebut ditujukan untuk melakukan evaluasi rutin mengenai perkembangan data lapangan terkait dengan kondisi anggota dalam menerapkan budidaya padi sehat.

Kegiatan ini difasilitasi oleh Pak Haz sebagai ketua Gapoktan Silih Asih. Untuk sumber pendanaan berasal dari kas Gapoktan Silih Asih yang dikelola oleh Pak Haz ${ }^{10}$. Selain untuk membiaya konsumsi pada setiap pertemuan, Pak Haz juga mengalokasi dana untuk memberi "uang pengganti transport" kepada para ketua kelompok sebesar Rp 50.000,- pada setiap bulannya, serta memfasilitasi perlengkapan kegiatan seperti buku

\footnotetext{
${ }^{9}$ Pertemuan diadakan setiap hari Kamis sesuai dengan kesepakatan kelompok. Hari kamis dipilih karena dinilai lebih leluasa akan menghadapi hari libur beraktivitas ke sawah. Hari libur bagi para petani setempat adalah hari Jumat. Hal ini dikarenakan pada hari Jumat, para petani yang umumnya dari golongan kaum laki-laki harus menjalani sholat jumatan sehingga kurang efektif apabila digunakan sebagai waktu kerja di sawah. Terkecuali pekerjaan yang hanya ditujukan untuk mengontrol kondisi lahan.

${ }^{10}$ Sumber dana Gapoktan Silih Asih berasal dari kegiatan pelatihan-pelatihan yang diselenggarakan atas kerjasama dengan instansi lain. Dari kegiatan pelatihan tersebut terdapat alokasi dana untuk menyewa ruang belajar, penginapan peserta dan pembiayaan fasilitas pelatihan lainnya.
} 
dan alat tulis, buku panduan dan kartu kendali budidaya padi sehat, juga buku standar operasional prosedur (SOP) budidaya padi sehat. Setiap minggunya, para ketua kelompok tani selaku MPM melaporkan kondisi anggota kelompoknya terkait dengan hal-hal sebagai berikut : (1) luas lahan garapan total pada masing-masing blok tanam, (2) luas lahan yang sedang ditanami padi, (3) jenis varietas padi yang sedang ditanam, (4) tanggal sebar benih padi, (5) tanggal tanam bibit padi, (6) Kebutuhan sarana produksi $(\mathrm{Kg})$ meliputi kebutuhan : benih, pupuk urea, pupuk SP8, pupuk phonska, dan pupuk organik, (7) catatan panen dan pemasaran meliputi : tanggal panen, jumlah produksi (ton), tempat menjual hasil panen, total hasil panen yang dijual, dan (8) keterangan.

Kegiatan pertemuan rutin dengan para ketua kelompok tani ini menjadi bagian dari kegiatan penyuluhan yang dilaksanakan oleh Pak Edd. Sebagai seorang penyuluh yang profesional, kegiatan penyuluhan yang diselenggarakan sangat kondusif untuk membantu para ketua kelompok tani memahami dan mampu menjalankan tanggung jawab khususnya terkait dengan gagasan pembentukan MPM ini. Dari hasil evaluasi kinerja MPM pada bulan pertama (Januari 2009), diketahui bahwa dari 6 kelompok tani, terdapat 4 kelompok tani yang sudah melaporkan perkembangan para anggotanya secara lengkap. Meskipun gagasan mengenai MPM ini muncul dari Pak Haz sebagai tokoh dan sekaligus ketua Gapoktan Silih Asih, namun gagasan ini direspon dengan positif oleh para ketua kelompok. Hal ini tampak dengan adanya partisipasi para ketua kelompok setempat untuk selalu menghadiri pertemuan rutin sebagaimana waktu yang telah disepakati bersama. Pada pertemuan tersebut dapat dibangun suatu diskusi interaktif dan dinamis antara para ketua kelompok, Pak Haz dan Pak Edd sebagai pendamping.

Sebagaimana yang telah dikemukakan oleh Pak Haz bahwa salah satu tujuan pengembangan pertanian organik di Kampung Ciburuy ini adalah untuk meregenasikan dan membuka lapangan pekerjaan bagi para taruna tani setempat. Untuk merealisasikan gagasan tersebut, pada pertengahan tahun 2008, Pak Haz dan Pak Edd menyelenggarakan kegiatan sekolah lapang. Sekolah lapang ini pada awalnya diselenggarakan selama 10 hari dengan didanai oleh Balai Besar Pendidikan dan Pelatihan Kesehatan Hewan (BBDPKH) Cinagara Bogor. Kegiatan ini diikuti oleh 23 orang taruna tani (pemuda laki-laki). Selama pelatihan, para peserta disewakan lahan seluas $3000 \mathrm{~m}^{2}$ sebagai tempat pelatihan $^{11}$. peserta diberi fasilitas makan siang dan uang sebesar Rp 40.000,- per hari. Materi pelatihan

\footnotetext{
${ }^{11}$ Pihak BBDPKH menyewa lahan seluas $3000 \mathrm{~m}^{2}$ ini kepada Pak Haz selaku pemilik lahan sebesar $\mathrm{Rp}$ 3.000.000,- Setelah kegiatan sekolah lapang selesai, selanjutnya lahan ini disewa oleh koperasi kelompok tani Lisung Kiwari kepada Pak Haz agar kegiatan budidaya padi sehat terus berlanjut.
}

yang diberikan adalah mengenai budidaya padi sehat, penangkaran benih padi, pembuatan dan penggunaan kompos jerami, pembuatan dan penggunaan LOF (Liquid Organic Fertilizer), pembuatan dan penggunaan pestisida nabati, dan budidaya ikan.

Kegiatan sekolah lapang ini tetap berlanjut meskipun tidak didanai kembali oleh BBDPKH. Para taruna tani menyusun jadwal piket untuk tetap memelihara padi yang sudah mereka tanam sesuai kesepakatan waktu diantara mereka. Setiap hari selama satu minggu ada tiga orang taruna tani yang bertugas untuk mengontrol kondisi lahan. Kinerja para taruna tani tersebut berada dalam pengawasan Pak Haz dan Pak Edd. Setiap taruna tani yang bertugas akan diberi "upah" sesuai dengan kebijakan Pak Haz dan Pak Edd" ${ }^{12}$.

Di samping kegiatan pertemuan rutin dengan kelompok tani dan sekolah lapang, selaku PPL di Kampung Ciburuy, Pak Haz selalu melibatkan Pak Edd dalam menerima kunjungan tamu dari berbagai instansi baik untuk pelatihan, studi banding, kegiatan penelitian mahasiswa, maupun kunjungan tamu kehormatan. Oleh karena hubungan antara penyuluh dan para petani setempat sudah terjalin dengan baik, maka sangat memudahkan Pak Edd dan Pak Haz untuk mengorganisir baik para ketua kelompok maupun warga sekitar dalam kegiatan yang memerlukan mobilisasi warga. Terlebih pada saat kampanye pemilu tahun 2008-2009 ini. Selaku tokoh terkemuka di tingkat nasional, Pak Haz dan Gapoktan Silih Asih di Kampung Ciburuy ini menjadi salah satu lokasi tujuan utama bagi para calon legislatif untuk menggalang suara massa. Salah satunya adalah mobilisasi warga saat menerima kunjungan dari Sultan Hamengku Buwono X. dalam acara Silaturahmi dan Temu Tani Anggota Kelompok Tani di 3 Kecamatan yaitu Kecamatan Cigombong, Kecamatan Caringin, dan Kecamatan Cijeruk, Gapoktan Silih Asih di Kampung Ciburuy mendapat kehormatan untuk menjadi tempat penyelenggaraan acara tersebut. Acara yang dihadiri oleh 250 orang ini melibatkan instansi pemerintahan, para petani, pemuda tani, dan wanita tani Dengan adanya koordinasi yang sangat baik antara Pak Haz, Pak Edd, para petani dan warga setempat, setiap kegiatan dapat berjalan dengan tertib dan lancar.

Diberlakukannya Surat Keputusan Bersama Menteri Dalam Negeri dan Menteri Pertanian Nomor 54 Tahun 1996/301/Kpts/LP.120/4/96, tentang Pedoman Penyelenggaraan Penyuluhan Pertanian dan Petunjuk Pelaksanaannya telah menjadi dasar bagi penyuluh di Kampung Ciburuy dalam menjalankan kegiatan penyuluhan. Namun untuk mencapai tujuan penyuluhan sesuai dengan kondisi dan potensi local, maka terdapat beberapa tata aturan yang dibangun melalui kesepakatan antara Pak Edd

\footnotetext{
${ }^{12}$ Upah diberikan dengan besaran "alakadarnya" atau dengan istilah "uang rokok"
} 
selaku penyuluh dan para petani selaku subjek penyuluhan. Seperti misalnya penentuan waktu pertemuan rutin untuk mengevaluasi kinerja manajer pengendali mutu dan topik-topik penyuluhan didasarkan pada kebutuhan untuk pengembangan program MPM yang dibutuhkan oleh para petani setempat. Jadi kepentingan penyuluh dan para petani dapat saling terpenuhi dimana penyuluh dapat menjalankan tugasnya menurut tata aturan formal penyelenggaraan penyuluhan namun tetap disesuaikan dengan tata aturan sesuai kebutuhan di tingkat petani. Dalam konteks ini tampak antara pilar regulatif dan pilar normatif saling menguatkan.

\section{Kelembagaan untuk Pengaturan Produksi}

Aktivitas produksi melibatkan kebutuhan tenaga kerja dan manajemen. Kebutuhan tenaga kerja dapat dipenuhi melalui terbentuknya kelembagaan hubungan kerja yang mencakup sistem pembagian kerja dan sistem upah. Adapun manajemen merupakan aktivitas pengambilan keputusan yang pada umumnya dilakukan oleh petani penggarap. Aktivitas pengambilan keputusan tersebut meliputi (1) pemahaman dan penentuan input, (2) memobilisasi, koordinasi, supervise, input tenaga kerja, (3) penentuan macam-macam dan durasi produksi, serta (4) meyakinkan keseimbangan antara input dan output. Aktivitas-aktivitas tersebut melibatkan pengeluaran dan pemasukan uang. Oleh karena itu, dalam mengambil keputusan para petani penggarap melakukan musyawarah dengan istri atau anggota keluarga mereka untuk memperoleh pilihanpilihan terbaik. Namun, pengambilan keputusan berada di tangan petani penggarap. Selain itu, pengaturan produksi juga mencakup kelembagaan panen yang terdapat di Kampung Ciburuy.

\section{Kelembagaan Hubungan Kerja}

Usaha bidang pertanian di Kampung Ciburuy ini tidak didasarkan atas ikatan-ikatan sosial sehingga menjadi suatu aktivitas komunal meskipun mayoritas warga setempat masih memiliki ikatan keluarga. Hubungan kerja pertanian pun didasarkan atas ekonomi uang dengan struktur majikan dan buruh tani baik buruh tetap maupun buruh lepas. Adapun kelembagaan hubungan kerja pertanian di kampung ini meliputi sistem pembagian kerja pertanian dan sistem upah.

\section{$\underline{\text { Sistem Pembagian Kerja }}$}

Dalam sistem produksi dan distribusi padi sehat di kampung ini terdapat sistem pembagian kerja menurut spesialisasi jenis pekerjaan tersebut. Ini berlaku baik untuk pekerja tetap maupun buruh lepas. Dari hasil penelitian diketahui bahwa para petani penggarap pun seringkali mengupah para buruh harian untuk bekerja di lahan garapannya. Jadi mereka tidak selalu mengerjakan sendiri untuk mengelola lahan garapan mereka. Hal ini dikarenakan petani penggarap tersebut memiliki lahan yang tersebar di beberapa blok-blok tanam sehingga membutuhkan tenaga tambahan, atau petani penggarap tersebut memiliki pekerjaan lain sehingga memerlukan buruh harian yang sudah biasa mengerjakan sawah. Namun, meskipun mereka memperkerjakan buruh harian yang sudah terbiasa mengerjakan sawah, akan tetapi para buruh tersebut tidak menjadi buruh tetap. Para petani penggarap pun dapat memperkerjakan siapa saja buruh harian yang mampu mengerjakan sawahnya tersebut.

Secara garis besar, jenis-jenis pekerjaan tersebut dibedakan untuk dikerjakan oleh laki-laki dan perempuan. Pak Haz menjelaskan, "Ini bukan gender, tapi ditinjau dari sisi kemampuan dan keahlian maka terdapat pekerjaan-pekerjaan yang cocok dikerjakan oleh laki-laki dan perempuan!"’. Untuk pekerjaan menanam padi (tandur) dan menyiangi rumput (ngarambet) hanya dikerjakan oleh pekerja perempuan, sedangkan pekerjaan mencangkul, membajak, membuat pematang, mengurus air dan panen semua kerjakan oleh pekerja laki-laki.

Pekerjaan-pekerjaan tersebut pun sudah terspesialisasi sehingga menjadi profesi orang-orang tertentu saja yang sudah terbiasa melakukan pekerjaan-pekerjaa tersebut. Misalnya operator bajak adalah Pak Jum dan Amr, jadi para petani di kampung ini yang akan membajak sawah sebagian besar menggunakan jasa mereka. Pak Jum dan Amr adalah pekerja tetap Pak Haz, dan oleh karena traktor-traktor tersebut adalah milik Pak Haz maka sebagian pendapatan dari sewa membajak harus diserahkan pada Pak Haz. Adapun tugas mengurus air dikerjakan oleh para petugas ulu-ulu yang bertanggung jawab pada masing-masing lokasi. Mereka berhak memperoleh upah dari setiap petani yang panen pada lahan dimana sistem pengairannya dikelola oleh ulu-ulu tersebut.

Demikian pula halnya pekerjaan membuat pupuk organik OFER yang dikerjakan oleh Pak Suk dan Pak Ron, di lokasi penjemuran padi ada Ibu Ynh dan anaknya, di lokasi penggilingan ada Pak Roi, Pak Udi, dan Pak Brn. Ibu Ynh dan Pak Roi adalah suami istri yang bertempat tinggal di lokasi penjemuran, penggilingan, dan pengeringan gabah tersebut. Mereka sudah hampir 18 tahun bekerja di tempat tersebut. Di penapian beras, ada 9 orang perempuan yang bekerja untuk membersihkan kotoran-kotoran pada beras SAE. Untuk packing beras dikerjakan oleh Kang Dcl. Adapun yang menjadi pekerja di koperasi adalah Kang Irk dan Kang Dng. Para pekerja tersebut bertanggung jawab untuk melaporkan hasil pekerjaan mereka kepada Pak Hk selaku ketua koperasi sekaligus pengelola distribusi beras SAE.

Oleh karena sistem pertukaran menggunakan uang, prinsip-prinsip efisiensi sangat diperhitungkan. Oleh karena itu, terbentuk hubungan kerja antara majikan dan pekerja tetap. Bagi para pekerja tetap, meskipun upah yang mereka peroleh lebih rendah dari upah yang berlaku umum, namun mendapat jaminan kepastian pekerjaan dan pendapatan menjadi alasan utama untuk menjaga hubungan kerja tersebut. 
Dengan adanya sistem pembagian kerja ini, juga terbentuk struktur organisasi baik di Gapoktan Silih Asih maupun di Koperasi Kelompok Tani "Lisung Kiwari" sebagaimana akan diuraikan pada profil kelembagaan-kelembagaan tersebut.

\section{$\underline{\text { Sistem Upah }}$}

Kisaran upah untuk pekerjaan-pekerjaan di sawah pada umumnya tidak jauh berbeda. Upah untuk buruh harian diberikan langsung pada hari setelah buruh tersebut menyelesaikan pekerjaannya. Waktu bekerja di sawah adalah pukul 07.00 sampai 11.30. Untuk buruh tetap, upah diberikan per minggu setiap hari kamis menjelang hari libur bekerja yang jatuh pada hari jum'at. Buruh harian lepas memperoleh upah yang sedikit lebih tinggi dibandingkan buruh tetap dengan perbandingan yang disajikan dalam Tabel 2. Adapun beberapa pekerjaan pertanian di luar sawah, memiliki sistem upah sebagaimana tercantum dalam Tabel 3.

Kelembagaan hubungan kerja dalam produksi padi sehat pada umumnya tidak didasarkan atas aturan tertulis. Hubungan antara petani penggarap dengan buruh tani dilandasi oleh komitmen dan kepercayaan yang dibangun oleh kedua belah pihak. Selain itu, juga didasari atas kepentingan kedua pihak dimana petani penggarap memerlukan buruh tani untuk menggarap lahannya dan buruh tani memerlukan upah dari hasil kerja yang telah dilakukannya. Ketentuan atas jenis pekerjaan dan besaran upah memang ditentukan oleh petani penggarap merujuk upah yang berlaku umum di masyarakat setempat. Namun hal ini harus disepakati oleh buruh tani baik buruh tetap maupun buruh harian. Para petani penggarap biasanya menggunakan tenaga buruh lepas yang sudah terbiasa mengerjakan lahannya dari musim ke musim.

Pada umumnya, untuk pekerjaan pertanian di sawah, buruh lepas memperoleh upah harian dari petani penggarap setelah bekerja dari pukul 07.0011.30. Adapun untuk buruh tetap memperoleh upah yang dibayarkan setiap minggunya pada hari Kamis. Jadi apabila buruh tani tidak mengerjakan lahan maka tidak memperoleh upah atau upah mingguan dipotong sejumlah hari kerja yang ditinggalkan. Apabila salah satu pihak melakukan pelanggaran atas kesepakatan kerja yang telah dirumuskan maka akan terjadi pemutusan hubungan kerja. Sehubungan dengan uraian di atas, maka kelembagaan hubungan kerja ini tampak ditopang oleh pilar normative.

\section{Kelembagaan Panen}

Kegiatan panen adalah salah satu kegiatan yang banyak membutuhkan tenaga kerja. Di Kampung Ciburuy ini, panen hanya dikerjakan oleh laki-laki. Ini terutama dikarenakan pada proses merontokkan padi (ngagebot) dilakukan hingga dini hari karena pada pagi hari padi baru saja dipotong (dibuat). Umumnya panen ini dilakukan dari pukul 07.00 hingga pukul 06.00 keesokan harinya, terkecuali bila hari sedang banyak turun hujan. Para petani penggarap pun menggunakan jasa buruh tani untuk mengerjakannya mulai dari memotong padi (dibuat), mengumpulkan padi yang sudah dipotong, merontokkan gabah (ngagebot pare), memasukkan gabah ke dalam karung, lalu mengangkutnya hingga ke pinggir jalan untuk kemudian di jual ke koperasi atau ke luar koperasi. Kebutuhan jumlah buruh tani tersebut tergantung luasan lahan yang akan dipanen.

Tabel 2. Sistem Upah pada Pekerjaan Pertanian di Sawah

\begin{tabular}{|c|c|c|c|}
\hline Status & $\begin{array}{c}\text { Jenis } \\
\text { Kelamin }\end{array}$ & $\begin{array}{c}\text { Jenis } \\
\text { Pekerjaan }\end{array}$ & Upah \\
\hline $\begin{array}{l}\text { Buruh } \\
\text { harian }\end{array}$ & Perempuan & $\begin{array}{l}\text { Menanam } \\
\text { padi } \\
\text { Menyiangi } \\
\text { rumput }\end{array}$ & $\begin{array}{l}\operatorname{Rp} 12.000,-- \\
\operatorname{Rp} 13.000,-\end{array}$ \\
\hline & \multirow[t]{2}{*}{ Laki-laki } & $\begin{array}{l}\text { Mencangkul } \\
\text { saja } \\
\text { Membuat } \\
\text { pematang saja }\end{array}$ & Rp 20.000,- \\
\hline & & Panen & $\begin{array}{l}\text { Upah } \\
\text { diberikan } \\
\text { secara } \\
\text { borongan, dari } \\
\text { mulai } \\
\text { memotong } \\
\text { padi sampai } \\
\text { mengantarkan } \\
\text { ke jalan raya } \\
\text { untuk } \\
\text { diangkut ke } \\
\text { tempat tempat } \\
\text { penjualan. } \\
\text { Umumnya } \\
\text { tergantung } \\
\text { luasan lahan. } \\
\text { Bila total } \\
\text { upah Rp } \\
\text { 300.000,- dan } \\
\text { dikerjakan } \\
\text { oleh 5 orang } \\
\text { pekerja maka } \\
\text { masing- } \\
\text { masing } \\
\text { pekerja } \\
\text { memperoleh } \\
\text { Rp 60.000,-. } \\
\text { Waktu } \\
\text { penyelesaian } \\
\text { pekerjaan } \\
\text { tergantung } \\
\text { pemakaian } \\
\text { tenaga kerja }\end{array}$ \\
\hline \multirow[t]{2}{*}{$\begin{array}{l}\text { Buruh } \\
\text { tetap }\end{array}$} & Perempuan & $\begin{array}{l}\text { Menanam } \\
\text { padi } \\
\text { Menyiangi } \\
\text { rumput }\end{array}$ & Rp 11.000,- \\
\hline & Laki-laki & $\begin{array}{l}\text { Berbagai jenis } \\
\text { pekerjaan }\end{array}$ & Rp 100.000,- \\
\hline
\end{tabular}

Sumber : Data Primer, 2009

Rata-rata luasan sawah yang digarap petani adalah sekitar $3000 \mathrm{~m}^{2}$, sehingga biasanya hanya melibatkan 3-5 orang buruh tani dan waktu pengerjaan panen pun hanya memakan waktu 1-2 hari saja. Pekerjaan panen ini diberikan secara 
borongan dengan upah Rp 200,- per kilogram gabah yang dihasilkan. Berapapun jumlah buruh tani yang ikut mengerjakan panen tersebut upah yang diberikan tetap sama, jadi semakin banyak orang yang ikut panen maka pendapatan masing-masing orang akan semakin lebih sedikit. Misalkan dari pengalaman Pak Jum, dari luasan sawah sekitar 1000 $\mathrm{m}^{2}$ dapat diperoleh gabah sebanyak $700 \mathrm{~kg}$. Jadi, upah yang diberikan kepada buruh tani untuk jasa memanen adalah Rp 140.000,-. Apabila buruh tani yang mengerjakan panen hanya 2 orang, maka masing-masing buruh tani memperoleh Rp 70.000,dan apabila buruh tani ada 3 orang, maka masingmasing buruh tani memperoleh sekitar Rp 46.700,--

Tabel 3. Sistem Upah pada Pekerjaan Pertanian di Luar Sawah

\begin{tabular}{|c|c|c|c|}
\hline $\begin{array}{c}\text { Jenis } \\
\text { Pekerjaan }\end{array}$ & Pekerja & Upah & Waktu Kerja \\
\hline $\begin{array}{l}\text { Membuat } \\
\text { pupuk organik } \\
\text { OFER dan } \\
\text { kompok }\end{array}$ & $\begin{array}{l}\text { Pak Suk } \\
\text { dan Pak } \\
\text { Ron }\end{array}$ & $\begin{array}{l}\text { Rp 25.000,-- } \\
\text { per hari } \\
\text { kerja }\end{array}$ & $\begin{array}{l}\text { Sabtu-Kamis } \\
07.00-11.30\end{array}$ \\
\hline $\begin{array}{l}\text { Menjemur } \\
\text { padi }\end{array}$ & $\begin{array}{l}\text { Ibu Ynh } \\
\text { dan } \\
\text { anaknya }\end{array}$ & $\begin{array}{l}\text { Rp 50,- per } \\
\text { kilogram } \\
\text { gabah basah }\end{array}$ & $\begin{array}{l}\text { Setiap hari bila } \\
\text { terdapat sinar } \\
\text { matahari yang } \\
\text { cukup, } \\
\text { maksimal } \\
\text { sampai pukul } \\
14.00 \text {. }\end{array}$ \\
\hline $\begin{array}{l}\text { Mengeringkan } \\
\text { padi di dryer }\end{array}$ & $\begin{array}{l}\text { Pak Roi } \\
\text { dan Pak } \\
\text { Emn }\end{array}$ & $\begin{array}{l}\text { Rp 50,- per } \\
\text { kilogram } \\
\text { gabah basah }\end{array}$ & $\begin{array}{l}\text { Bila hari selalu } \\
\text { mendung dan } \\
\text { tidak ada sinar } \\
\text { matahari yang } \\
\text { cukup untuk } \\
\text { mengeringkan } \\
\text { gabah } \\
\text { Setiap hari dari } \\
07.00-00.00 \\
\end{array}$ \\
\hline $\begin{array}{l}\text { Menggiling } \\
\text { padi }\end{array}$ & $\begin{array}{l}\text { Pak Roi } \\
\text { Pak Udi } \\
\text { Pak Brn }\end{array}$ & $\begin{array}{l}\text { Rp } 25.000,- \\
\text { per hari } \\
\text { kerja }\end{array}$ & $\begin{array}{l}\text { Sabtu-Kamis } \\
07.30-15.30\end{array}$ \\
\hline Menapi beras & $\begin{array}{l}9 \text { orang } \\
\text { perempuan }\end{array}$ & $\begin{array}{l}\text { Rp 100,- per } \\
\text { kilogram } \\
\text { Apabila } \\
\text { borongan } \\
\text { diupah } \\
\text { masing- } \\
\text { masing } \\
\text { penapi Rp } \\
15.000 \text { per } \\
\text { hari (dari } \\
\text { jam 06.30- } \\
15.30)\end{array}$ & $\begin{array}{l}\text { Sabtu-Kamis } \\
06.30-11.30\end{array}$ \\
\hline $\begin{array}{l}\text { Bekerja di } \\
\text { koperasi }\end{array}$ & $\begin{array}{l}\text { Kang Irk } \\
\text { Kang Dng }\end{array}$ & $\begin{array}{l}\text { Rp } 150.000,- \\
\text { per bulan }\end{array}$ & $\begin{array}{l}\text { Setiap hari } \\
07.30-15.00\end{array}$ \\
\hline $\begin{array}{l}\text { Packing beras } \\
\text { SAE }\end{array}$ & Kang Dcl & $\begin{array}{l}\text { Rp } 400.000,- \\
\text { per bulan } \\
\text { dibayar oleh } \\
\text { LPS }\end{array}$ & $\begin{array}{l}\text { Setiap ada } \\
\text { beras SAE } \\
\text { yang siap } \\
\text { packing }\end{array}$ \\
\hline $\begin{array}{l}\text { Ketua } \\
\text { Koperasi }\end{array}$ & Kang Hk & $\begin{array}{l}\text { Rp 200.000,- } \\
\text { per bulan }\end{array}$ & $\begin{array}{l}\text { Setiap hari } \\
07.30-15.00\end{array}$ \\
\hline $\begin{array}{l}\text { Sekretaris } \\
\text { Koperasi }\end{array}$ & Pak Sum & $\begin{array}{l}\text { Rp } 200.000,- \\
\text { per bulan }\end{array}$ & $\begin{array}{l}\text { Setiap hari } \\
07.30-15.00\end{array}$ \\
\hline Bendahara & Kang Hp & $\begin{array}{l}\text { Rp } 200.000,- \\
\text { per bulan }\end{array}$ & $\begin{array}{l}\text { Setiap hari } \\
07.30-15.00\end{array}$ \\
\hline
\end{tabular}

\begin{tabular}{|l|l|l|l|}
\hline Badan & Pak Haz & $\begin{array}{l}\text { Rp 200.000,- } \\
\text { per bulan }\end{array}$ & $\begin{array}{l}\text { Setiap hari } \\
07.30-15.00\end{array}$ \\
\hline Badang & Pak Jks & Rp 200.000,- & Setiap hari \\
Pengawas & & per bulan & $07.30-15.00$ \\
\hline
\end{tabular}

Sumber : Data Primer, 2009

Untuk lokasi sawah yang berjarak cukup jauh dari jalan raya, maka terdapat tambahan ongkos angkut sampai pinggir jalan sebesar $\mathrm{Rp}$ 50,- per kilogram. Pada umumnya, setelah gabah yang dipanen tersebut sudah berada di pinggir jalan, petani penggarap lahan menghubungi Kang $\mathrm{Hk}$ untuk menjemput gabah yang akan mereka jual ke koperasi dengan mobil. Apabila lokasi pengangkutan cukup jauh (sekitar lebih dari $700 \mathrm{~m}$ ), seperti halnya dari lokasi lahan Pak Hnd, maka biaya pengangkutan gabah dari pinggir jalan ke koperasi ini adalah sebesar Rp 100,- per kilogram.

Pada kelembagaan panen ini, hubungan antara petani penggarap, buruh tani, dan Kang Hk didasarkan atas komitmen dan kepercayaan. Meskipun tidak didasarkan pada tata aturan tertulis, namun ketiga pihak berkepentingan memperoleh keuntungan dari aktivitas panen ini. Petani penggarap memperoleh uang dari hasil penjualan gabah, buruh tani memperoleh upah dari pekerjaan memanen padi, dan Kang Hk memperoleh uang dari jasa transportasi angkutan panen. Sebagaimana aktivitas produksi, aktivitas panen pun memerlukan tenaga buruh tani yang ahli dalam arti terbiasa mengerjakan sawah termasuk panen. Bagi para petani penggarap yang tidak memiliki buruh tetap, maka pada umumnya menggunakan buruh tani yang sudah terbiasa mengerjakan sawah garapan petani tersebut. Sebagian besar komunitas petani padi sawah di Kampung Ciburuy menjual gabahnya ke koperasi setempat. Sehubungan dengan itu, untuk kemudahan, para petani menggunakan jasa pengangkutan hasil panen dari Kang Hk untuk mengangkut gabah dari pinggir jalan ke koperasi untuk sekaligus dijual ke koperasi setempat tadi. Apabila salah satu pihak tidak memenuhi aturan panen yang dilakukan, maka akan menyebabkan hilangnya kepercayaan dari pihak-pihak lain yang terlibat. Dari uraian di atas maka kelembagaan panen ini tampak ditopang oleh pilar normatif (Tabel 19).

\section{Kelembagaan untuk Pengaturan Output}

Aktivitas output meliputi penyimpanan (setelah panen atau pengolahan), pengolahan (pengolahan secara manual atau dengan mesin), penggunaan transportasi (baik untuk pengolahan, penyimpanan, dan penjualan), serta pemasaran. Aktivitas output ini berjalan dengan didasarkan pada aturan-aturan yang berlaku di Kampung Ciburuy. Kelembagaan yang terbentuk adalah kelembagaan pasca panen dan kelembagaan distribusi beras SAE sebagai produk dari padi sehat.

\section{Kelembagaan Pasca Panen}

Kegiatan panen selesai sampai gabah yang dihasilkan dimasukkan ke dalam karung dan 
disimpan di pinggir jalan. Para petani yang panen kemudian menghubungi Kang Hk agar menjemput hasil panen dengan mobil koperasi. Dari hasil penelitian diketahui bahwa proses pasca panen menjadi faktor penting dalam proses produksi beras SAE ini. Beras SAE dapat diproduksi dan dipasarkan hingga saat ini melibatkan proses-proses penjemuran, penggilingan, penapian, dan pengemasan. Setiap proses memiliki tata aturan tersendiri dan pola-pola hubungan yang khas sehingga membentuk kelembagaan tersendiri dalam rangka memproduksi beras sehat tersebut sebagaimana yang diuraikan berikut ini. Namun, pada intinya semua proses tersebut terkait dengan koperasi. Setiap petani menjual gabah yang dipanennya ke koperasi yaitu ke Kang Hk. Proses selanjutnya berada di bawah pengelolaan Kang Hk. Sebagai ketua koperasi dan anak dari tokoh masyarakat terkemuka di Kampung Ciburuy, Kang Hk berwenang untuk mengelola hubungan kerja dalam proses pasca panen dan proses distribusi beras SAE. Dalam konteks ini, Kang Hk menjadi "majikan" yang memiliki sejumlah pekerja (buruh) baik pada proses penjemuran, penggilingan, penapian dan pengemasan beras ${ }^{13}$. Jadi, semua pekerja bertanggung jawab kepada Kang Hk dan Kang HK berkewajiban memberikan gaji/upah kepada para pekerja tersebut.

Selain itu, oleh karena lokasi proses-proses pasca panen ini berada di lahan PT. BSS dan lahan milik adik Pak Haz, maka Kang Hk pun berkewajiban untuk membayar sewa lahan. Lokasi penjemuran dan penggilingan beras berada di lahan PT. BSS. Setiap tahun Kang Hk membayar biaya sewa lahan sebesar Rp 2.500.000,- kepada PT. $\mathrm{BSS}^{14}$. Adapun lahan yang digunakan untuk penapian dan pengemasan beras SAE berada dalam satu lokasi lahan dengan koperasi. Lahan tersebut adalah milik adiknya Pak Haz. Lahan tersebut sudah dikuasakan kepada Pak Haz. Jadi, Kang HK membayar biaya sewa lahan tersebut kepada Pak Haz sebesar Rp 600.000,- per tahun.

Dalam sistem pembayaran upah pada proses pasca panen untuk para pekerja (buruh) yang bekerja pada Kang Hk sama dengan pada proses produksi yaitu diberikan pada hari kamis setiap minggunya. Adapun hari libur kerja juga ditetapkan pada hari Jum'at. Dalam hal aturan kerja, tidak ada aturan secara tertulis yang menjelaskan deskripsi pekerjaan, hak dan kewajiban antara Kang $\mathrm{Hk}$ "majikan" dan semua pekerjanya (buruh). Hubungan kerja pada umumnya dilakukan atas dasar komitmen, kepercayaan, tanggung jawab kedua pihak. Kemudahan hubungan kerja ini ditunjang dengan adanya kemudahan komunikasi. Oleh karena berada dalam lokasi yang relatif berdekatan,

\footnotetext{
13 Untuk pengemasan beras SAE masih terlibat kerjasama dengan pihak LPS.

${ }^{14}$ Pembayaran diberikan melalui Satpam PT. BSS sebagai orang kepercayaan perusahaan tersebut yang berdomisili di Kampung Ciburuy untuk kemudahan transaksi.
}

informasi yang terkait dengan pekerjaan ini lebih mudah untuk disampaikan. Pekerjaan dalam proses penggilingan beras terkadang tidak selalu ada karena ditentukan oleh jumlah gabah yang sudah dijemur. Bila harus menggiling beras, dengan segera para pekerja dapat ditemui ke rumahnya atau menitip pesan kepada tetangga dekatnya yang kebetulan datang ke koperasi untuk masuk bekerja. Terlebih dalam proses penapian yang ditentukan oleh adanya ketersediaan beras yang sudah digiling. Bila sudah tersedia, maka para pekerja dipanggil dengan memberi pesan dari mulut ke mulut. Terkait dengan peraturan secara teknis, pada proses penggilingan dan proses penapian (pengayakan beras) sudah ada peraturan secara tertulis .

\section{$\underline{\text { Penjemuran Gabah }}$}

Hampir seluruh petani di Kampung Ciburuy ini menjual hasil panen padi mereka ke koperasi. Seluruh gabah yang telah dijual ke koperasi menjadi milik atas nama Kang HK. Gabah tersebut kemudian masuk ke lokasi penjemuran. Ibu Ynh dan anaknya bekerja kepada Kang Hk di penjemuran beras ini. Ibu Ynh telah bekerja selama 14 tahun. Pekerjaan ini diberikan secara borongan dengan upah yang diberikan adalah Rp 50,- per kilogram gabah basah yang akan dijemur. Bila hari sedang cerah dan terdapat sinar matahari yang cukup untuk menjemur gabah. Ibu Ynh bekerja dari pukul 06.30 sampai maksimal pukul 15.00. apabila menjemur gabah lebih lama dari waktu tersebut akan dihasilkan kualitas gabah yang kurang bagus, terlebih gabah untuk bibit padi. Untuk memperoleh kualitas terbaik, gabah untuk bibit hanya dijemur dari jam 11.00 hingga pukul 14.00 saja dalam keadaan sinar matahari sempurna. Apabila sedang musim hujan dan sinar matahari sangat minim bahkan hampir tidak ada sinar matahari, maka gabah dikeringkan di tempat pengeringan (dryer) ${ }^{15}$. Operator di mesin pengeringan ini adalah Pak Roi dan Pak Emn. Pekerjaan ini juga diberikan secara borongan dengan upah Rp 50,- per kilogram gabah basah yang akan dikeringkan.

\section{Penggilingan Beras}

Gabah yang telah kering kemudian digiling. Proses penggilingan ini dikerjakan oleh 3 operator yaitu Pak Roi, Pak Udi, Pak Brn. Upah yang diberikan adalah Rp 25.000,- per hari kerja. Mereka bekerja dari pukul 07.30 sampai pukul 15.30, bila terdapat gabah yang siap giling. Jadi, apabila tidak ada gabah kering yang siap digiling maka mereka tidak bekerja dan tidak mendapat upah. Pak Roi dan

\footnotetext{
${ }^{15}$ Secara kualitas, gabah yang dikeringkan dengan dryer seringkali tidak bisa kering dengan sempurna sebagaimana dengan sinar matahari. Ketika masuk dalam proses penggilingan pun, bulir beras yang dihasilkan banyak yang hancur dan tidak banyak menghasilkan bulir yang utuh. Harga jual pun menurun dan tidak bisa masuk dalam kategori beras SAE. Beras ini masuk dalam kualitas beras SAE pada level ketiga dan dijual ke pasar tradisional.
} 
Pak Brn sudah bekerja selama hampir 14 tahun, sedangkan Pak Udi sudah bekerja selama 8 tahun. Pada proses penggilingan, terdapat 3 mesin yaitu mesin perontok kulit gabah, alat pengayak (ranggon), dan mesin pemutih beras. Operator mesin pertama adalah Pak Roi, operator alat pengayak (ranggon) adalah Pak Udi, dan operator mesin ketiga adalah Pak Brn.

Selain bertugas pada alat pengayak, Pak Udi juga bertugas untuk mengikat karung yang sudah dipenuhi beras dengan bobot $25 \mathrm{~kg}$ dan mengangkutnya ke gudang. Pak Udi juga yang bertugas untuk melayani pembeli beras, pengguna jasa penggilingan, pembeli dedak, dan harus melaporkan pendapatan harian kepada Kang $\mathrm{Hk}$ setiap sore setelah penggilingan tutup. Pak Udi juga bertanggung jawab atas kunci ruang penggilingan dan gudang beras sekaligus menjadi orang kepercayaan Kang Hk selama ini. Hubungan kerja tersebut dapat berlangsung lama dengan didasari atas komitmen, kepercayaan, dan tanggung jawab antara kedua pihak. Selain pemberian upah pokok, Pak Udi diperbolehkan untuk mengambil margin dari setiap penjualan beras yang telah digiling ${ }^{16}$. Beras yang telah digiling dijual kepada para pembeli dengan harga Rp 5200,- per kilogram, sedangkan dedak dijual dengan harga Rp 1500,- per kilogram. Adapun untuk jasa penggilingan beras, harga untuk para tengkulak atau pengumpul beras adalah sebesar $\mathrm{Rp}$ 300,- per kilogram sedangkan untuk bukan tengkulak adalah Rp 500,- per kilogram.

\section{Penapian Beras}

Penapian beras dilakukan untuk menghasilkan beras SAE yang memiliki bulir utuh sempurna, seragam, dan bersih dari segala kotoran seperti batu, ulat, sampah, gabah (serah), dan dedak. Proses ini menjadi penting untuk memenuhi permintaan pasar sekaligus meningkatkan harga jual beras yang dihasilkan dari komunitas petani padi di Kampung Ciburuy ini. Penapian beras ini dilakukan oleh 9 orang perempuan yang sudah biasa menjadi pekerja khusus di penapian beras milik Kang Hk. Para pekerja sudah tetap sehingga tidak menerima pekerja lain yang ingin bekerja di penapian tersebut. Demikian pula apabila salah seorang pekerja tidak hadir maka tidak dicari orang lain untuk menggantikannya. Upah yang diberikan adalah $\mathrm{Rp}$ 100 ,- per kilogram yang berhasil dibersihkan oleh masing-masing penapi. Mereka bekerja dari jam 06.30 sampai pukul 11.30. Apabila ada pekerjaan menapi beras borongan, upah yang diberikan adalah sebesar Rp 15.000,- dengan jam kerja dari pukul 06.30 sampai dengan 15.30. Masing-masing penapi

16 Hasil penjualan dilaporkan kepada Kang HK dengan harga jual Rp 5000,- per kilogram. Beras dari penggilingan tersebut dijual oleh Pak Udi sebesar Rp 5200,- per kilogram. Jadi, Pak Udi memperoleh margin Rp 200,- per kilogram dari setiap penjualan beras yang dilayaninya. memasukkan beras yang sudah dibersihkan ke dalam karung beras yang sudah tersedia. Masing-masing karung berbobot 25 kilogram beras.

\section{$\underline{\text { Pengemasan Beras }}$}

Beras yang sudah bersih melalui proses penapian kemudian dikemas (Lampiran 8, Foto 2). Pekerja packing beras ini adalah Kang Dcl. Beliau sudah bekerja selama hampir 4 tahun, sejak koperasi membangun kerjasama dengan LPS. LPS menyediakan plastik pengemas dan juga membayar upah Kang DCL. Setiap bulan upah yang diberikan adalah sebesar Rp 400.000,-. Kang DCL bertanggung jawab untuk mengemas beras SAE dengan jumlah sesuai pesanan LPS. Setelah selesai dikemas, Pak Aph - sopir LPS yang memasarkan beras SAE - mengangkut beras SAE pesanan LPS dengan mobil milik LPS. Setiap bulan pihak koperasi (Kang Hk) harus dapat memenuhi target pesanan LPS sebanyak $8-20$ ton, namun pada realisasinya target yang terpenuhi hanya $4-6$ ton. Pihak LPS membeli beras dari koperasi kelompok tani Lisung Kiwari dengan harga Rp 6000,- per kilogram dan menjual kembali dalam bentuk kemasan 5 kiloan dengan harga $\mathrm{Rp} 39.000,-$. Di tingkat konsumen, beras SAE dijual dengan harga Rp 42.000,- dalam bentuk kemasan 5 kiloan.

Sebagaimana halnya kelembagaan produksi dan kelembagaan panen, kelembagaan pasca panen pun tampak ditopang oleh pilar normatif. Tata aturan baik pada aktivitas penjemuran gabah, penggilingan gabah, penapian beras dan pengemasan beras SAE tidak didasarkan pada tata aturan tertulis. Keempat aktivitas tersebut berada di bawah tanggung jawab Kang Hk selaku ketua koperasi sehingga tata aturan kerja pun ditentukan oleh Kang Hk. Sebagaimana hubungan antara majikan dan buruh maka kedua belah pihak berkepentingan dalam aktivitas pasca panen ini. Kang Hk selaku majikan memerlukan para buruh untuk mengerjakan penjemuran gabah, penggilingan, penapian dan pengemasan hingga memperoleh beras SAE yang siap dipasarkan pada konsumen. Adapun para buruh berkepentingan untuk memperoleh upah dari pekerjaan tersebut. Apabila salah satu pihak tidak memenuhi hak dan kewajiban yang telah ditentukan maka akan terjadi konsekuensi-konsekuensi. Seperti halnya apabila ada buruh tidak masuk bekerja, maka upah hari tersebut tentu tidak dibayarkan. Meskipun para buruh tersebut termasuk buruh tetap, namun upah yang diberikan adalah upah harian.

\section{Kelembagaan dalam Sistem Distribusi Beras SAE} Komunitas petani setempat ada yang menjual seluruhnya ke Koperasi Kelompok Tani Lisung Kiwari (selanjutnya disebut dengan koperasi), menjual sebagian ke koperasi dan sebagian ke luar koperasi, ada pula petani yang tidak menjual seluruh gabahnya untuk disimpan menjadi cadangan konsumsi keluarga. Namun, pada umumnya petani di Kampung Ciburuy ini selalu 
menyisihkan sebagian gabahnya untuk disimpan menjadi cadangan konsumsi keluarga.

Keberlanjutan sistem pertanian organik dalam hal ini adalah sistem pertanian padi sehat - di Kampung Ciburuy ini, sangat didukung dengan adanya kelembagaan dalam sistem distribusi produk beras SAE tersebut. Dalam sistem distribusi beras SAE dijelaskan siapa dan bagaimana para pelaku menjalankan proses pemasaran beras tersebut hingga dapat memenuhi permintaaan pasar konsumen). Pertama, hubungan antara para anggota kelompok tani dengan koperasi adalah : bahwa merujuk pada kesepakatan/tata aturan koperasi sebagai penerima dana LUEP, anggota kelompok-kelompok tani tersebut menjual gabahnya kepada koperasi kelompok tani Lisung Kiwari dengan target produksi yang sudah disepakati. Koperasi melalui Ketua Koperasi membayar secara tunai penjualan gabah tersebut kepada para petani. Sebaliknya, koperasi dapat memberikan pinjaman sarana produksi yang diperlukan para anggota kelompok tani untuk memperlancar proses produksi padi. Para petani tersebut melunasi hutang sarana produksi dengan cara dipotong dari uang pembayaran penjualan gabah pada saat panen (yarnen). Kedua, kelompokkelompok tani yang menjadi produsen/supplier adalah anggota Koperasi Kelompok Tani Lisung Kiwari. Kelima kelompok tani merupakan anggota dari Gapoktan (Gabungan Kelompok Tani) Silih Asih yang diketuai oleh Pak Haz. Kelompokkelompok tani tersebut memiliki dinamika yang berbeda dan hal ini dipengaruhi oleh peran ketua kelompok pada masing-masing kelompok tani. Pada umumnya, kelompok-kelompok tani tersebut berada dalam koordinasi ketua kelompok sehinggga beberapa proses yang terkait dengan koperasi lebih banyak/seringkali terkait dengan tanggung jawab penuh ketua kelompok. Seperti misalnya dalam hal peminjaman sarana produksi atas sepengatahuan ketua kelompok dan menjual gabah pun pada ketua kelompok untuk kemudian dijual ke koperasi. Ketua kelompok memegang peranan penting dalam kelancaran sarana produksi padi di wilayah ini. Ketiga, selain digunakan untuk kepentingan komersial, para anggota kelompok tani pun menyimpan hasil panen padi mereka untuk persediaan sampai panen pada musim berikutnya. Para petani menyadari pentingnya fungsi subsistensi ini untuk menjamin kelangsungan pangan keluarganya. Biasanya cadangan hasil panen tersebut berupa gabah yang siap untuk digiling. Jadi, petani harus mengeringkan padinya sendiri terlebih dahulu sebelum disimpan. Besarnya cadangan/simpanan panen ini beragam tergantung total hasil panen (produktivitas). Ada yang sebagian dijual dan sebagian disimpan, ada pula yang disesuaikan dengan jumlah anggota keluarganya. Keempat, gabah yang dihasilkan kemudian disimpan, juga terkadang dijual oleh petani tersebut kepada tetangga yang membutuhkan. Penjualan umunya dilakukan dengan istilah ngagentosan beas atau menukarkan sejumlah uang untuk membeli beras simpanan para petani penggarap. Harga penjualan relatif sama dengan harga yang berlaku umum, hanya saja karena adanya ikatan hubungan ketetanggaan, pertukaran pun tidak kaku seperti halnya jual beli di warung. Kelima, Koperasi Kelompok Tani Lisung Kiwari merupakan kelembagaan usaha ekonomi pedesaan yang dalam menjalankan aktivitasnya membutuhkan permodalan. Dari buku laporan pertanggungjawaban pengurus koperasi Lisung Kiwari tahun 2008, diketahui bahwa modal koperasi tersebut bersumber dari modal sendiri (simpanan pokok, simpanan wajib, cadangan, donasi, dan SHU tahun berjalan), modal dari luar (bantuan dana bergulir dari Kementrian Koperasi dan Usaha Kecil Menengah sejak Februari 2006 sebesar Rp 80.500.000,- dan bantuan pinjaman lunak dari BLM Lumbung Pangan sebesar Rp 17.000.000,-), serta bantuan modal dari DPM (Dana Penguatan Modal) LUEP sebesar 275.000.000,-. Tata aturan permodalan diatur berdasarkan peraturan-peraturan dan kesepakatankesepakatan yang dibuat antara pengurus koperasi dengan individu maupun lembaga yang terkait dalam mekanisme pengelolaan modal tersebut. Seperti halnya dalam pengelolaan modal sendiri, dalam hal ini anggota koperasi menjadi individu yang harus tunduk pada peraturan koperasi mengenai kewajiban anggota membayar simpanan pokok dan simpanan wajib. Keenam, selain itu, juga seperti halnya dalam pengelolaan dana pinjaman dari DPM LUEP, tata aturan didasarkan atas SK. Menteri Pertanian Nomor 149/Kpts/OT.140/3/2004 dan dioperasionalikan sebagaimana kesepakatan-kesepakatan antara pengurus koperasi (dalam hal ini diwakili oleh ketua koperasi), ketua kelompok tani (diwakili oleh ketua kelompok) dan pihak DPM LUEP (diwakili oleh ketua tim teknis Kabupaten Bogor). Ketersediaan modal tersebut membantu koperasi dalam melakukan pembelian gabah secara tunai kepada petani dan pemasaran beras sehingga dapat memenuhi target pemesanan para konsumen. Selain itu, koperasi juga dapat menggunakan modal tersebut untuk menyediakan sarana produksi pertanian dan pemberian kredit pertanian kepada para petani yang membutuhkan. Implikasi lebih lanjut adalah para petani dapat secara kontinyu memproduksi beras SAE serta dapat memenuhi kebutuhan konsumen. Ketujuh, Ddengan dukungan kelembagaan permodalan dan adanya kerjasama dengan LPS khususnya, maka koperasi dapat memproduksi beras dengan label beras SAE (sehat, aman, enak). Beras ini memiliki 3 tingkatan kualitas secara fisik, namun secara non-fisik beras ini tidak mengandung residu pestisida. Kualitas yang pertama adalan beras dengan bulir utuh dan relatif seragam (disebut dengan beras kepala), kualitas kedua adalah beras dengan bulir campuran (sebagian besar utuh, tapi bercampur dengan bulir beras yang pecahpecah), dan beras ketiga (disebut beras curah) adalah beras yang sebagian besar mengandung bulir yang pecah-pecah. Beras kualitas pertama dan kedua adalah beras yang dijual kepada lembaga-lembaga yang bekerjasama/bermitra dengan koperasi, 
sedangkan beras dengan kualitas ketiga dijual ke pasar tradisional dan kepada masyarakat sekitar. Hal ini dikarenakan adanya perbedaan preferensi konsumen, dimana konsumen di pasar tradisional dan masyarakat sekitar lebih memilih beras dengan harga murah meskipun secara fisik bukan beras kepala. Akan tetapi, preferensi konsumen di luar masyarakat sekitar khususnya lembaga mitra lebih memilih beras yang dikemas, dan secara fisik berbulir utuh, seragam serta bersih meskipun harganya relatif lebih mahal. Beras SAE tidak dijual ke supermarket untuk menghindari mekanisme prosedur penjualan yang rumit dan birokratif. Baik koperasi dan LPS khususnya yang terlibat dalam proses produksi (sampai pasca panen) dan distribusi sepakat untuk menjual beras SAE ke konsumen langsung sehingga dapat meminimalisasi kerugian biaya dan waktu yang dikeluarkan untuk menjalani prosedur dan birokasi dengan supermaket tersebut.

Dalam kelembagaan distribusi beras SAE ini, koperasi juga membangun hubungan kerjasama (kemitraan) dengan beberapa lembaga seperti dengan LPS (Lembaga Pertanian Sehat), Dompet Dhuafa Republika, Koperasi PT Coat Rejo di Bogor (untuk para karyawan), Koperasi PMI Bogor (untuk para perawat), Koperasi Oriza Sativa, Koperasi STPP Cinagara Bogor, Distanhut, Pensiunan Unilever (untuk para pensiunan), Indokonsul (untuk para pegawai), pertanian organik sayur, Agronutrisi, Agro Pest Indo Raya. Kerjasama yang dimaksud adalah adanya kontrak/kesepakatan pemesan beras SAE secar rutin per bulan dari lembaga mitra kepada koperasi. Bentuk-bentuk kesepakatan tersebut beragam tergantung kebutuhan dan kemampuan para lembaga mitra. Seperti misalnya kerjasama antara koperasi dengan LPS dibuat dalam bentuk kesepakatan kerjasama secara tertulis berupa MOU. LPS memesan beras SAE per bulan sebanyak 8-10 ton untuk memenuhi kebutuhan konsumennya. Pemesanan dilakukan secara bertahap. Adapun pihak koperasi harus menyediakan beras SAE sejumlah yang sudah disepakati dalam MOU tersebut. Dalam hal ini, pihak koperasi menjamin ketersediaan beras SAE dan LPS menjamin pasar untuk beras SAE sehingga kedua pihak memperoleh keuntungan yang bersifat kontinyu setiap bulannya. Kerjasama yang didasarkan pada kesepakatan tertulis ini, pada praktiknya berjalan dengan fleksibel. Menurut pihak LPS, koperasi terkadang hanya dapat memenuhi target pesanan sebanyak 4-6 ton. Hal ini dikarenakan faktor musim dan faktor lainnya yang berpengaruh terhadap proses produksi beras SAE. Adapun menurut ketua koperasi, pembayaran yang diberikan oleh pihak LPS terkadang terjadi keterlambatan karena tergantung dari penerimaan pembayaran di tingkat konsumen.

Hubungan kerjasama dilakukan atas dasar kepercayaan dan saling pengertian. Jadi kedua pihak memaklumi adanya ketidaksesuaian antara MOU dengan pelaksanaan sejauh masih dalam koridor yang tidak merugikan bagi kedua pihak. Oleh karena itu, hubungan kerjasama pun dapat berlangsung hingga kini. Selama kesepakatan yang dibangun dapat dijalankan oleh kedua pihak maka kerjasama dapat berlangsung terus. Adanya perubahan pada aturan yang ingin diterapkan oleh kedua pihak maka akan merubah bentuk kerjasama terebut. Hal ini tampak pada hubungan antara koperasi dengan PT. Coat Rejo. Pada kesepakatan pertama, koperasi memenuhi pesanan perusahaan dan perusahaan memberikan pembayaran setiap dua minggu sekali. Setelah berjalan selama 2 tahun, pihak perusahaan menyampaikan bahwa pihaknya hanya dapat memberikan pembayaran sebulan sekali. Adanya perubahan mekanisme pembayaran tersebut memberatkan pihak koperasi karena perputaran modal akan terhambat. Oleh karena itu, kerjasama tersebut sudah tidak berlanjut.

Pada kelembagaan distribusi Beras SAE, bentuk-bentuk kerjasama dan transaksi jual beli dengan instansi di luar Kampung Ciburuy hanya dilakukan melalui koperasi. Jadi, para petani setempat yang memiliki gabah dan hendak dijual sendiri, pada umumnya hanya dijual pada masyarakat sekitar. Hubungan kerjasama antara koperasi dengan LPS sudah berlangsung hampir selama 5 tahun. Untuk menjamin pasar dari penjualan beras SAE ini, pihak LPS membangun kerjasama dengan lembaga yang bertindak baik sebagai agen beras SAE maupun konsumen langsung. Beberapa agen beras SAE yang bermitra dengan LPS adalah Plaza Al-Ghifari Pajajaran Bogor, Swalayan Al-Amin di Bubulak Bogor, Pak Rht di Sindabarang Bogor, Koperasi SMA Rimba di Ciomas Bogor, Pak Zni di Villa Cimanggu Bogor, Ibu La di Bogor Baru, Ibu Agn di Bekasi, Pasar Anyar Bogor, dan Rumah Sakit Dr. Cipto Mangunkusumo di Jakarta. Hubungan kerjasama tersebut dilakukan berdasarkan kesepakatan tertulis dalam bentuk perjanjian jual beli dengan penyerahan uang muka, konsinyasi (pembayaran setelah beras SAE laku terjual), atau penentuan kesepakatan tenggat waktu pembayaran atas pembelian sejumlah beras SAE. Masing-masing agen distribusi beras SAE memiliki konsumen tersendiri yang pada umumnya membeli beras SAE secara eceran. Beberapa lembaga mitra merupakan konsumen langsung dari koperasi. Dalam arti, beras SAE yang dipesan ditujukan untuk memenuhi kebutuhan para anggota lembaga tersebut. Seperti halnya PT. Coat Rejo, memesan beras SAE untuk kebutuhan makan siang para karyawannya, Koperasi PMI Bogor memesan beras SAE untuk para perawatnya, dan Unilever memesan beras SAE untuk para pensiunannya. Demikian pula untuk pasar tradisional.

Merujuk pada uraian di atas, diketahui bahwa kelembagaan distribusi beras SAE ditopang oleh pilar normative. Hal ini tampak dimana kelembagaan ini muncul dengan adanya kesepakatan-kesepakatan antara pihak-pihak terkait untuk mendefinisikan tujuan yang diharapkan dan merancang langkah-langkah yang tepat untuk mencapai tujuan tersebut. Semua pihak dalam 
kelembagaan distribusi beras SAE ini memiliki kepentingan. Para petani berkepentingan untuk memperoleh keuntungan dari penjualan gabah ke koperasi. Selain itu, para petani dapat segera memperoleh uang tunai karena pihak koperasi membayar tunai hasil penjualan gabah tersebut. Koperasi sendiri berkepentingan untuk memperoleh keuntungan dari penjualan beras dari padi sehat tersebut dan memperoleh jaminan pasar yang sustain untuk distribusi beras SAE agar koperasi pun selalu memiliki uang tunai untuk membayar pembelian gabah dari petani. Adapun lembaga pertanian sehat berkepentingan untuk memperoleh keuntungan dari penjualan beras SAE yang sustain dengan adanya jaminan supply beras SAE dari koperasi. Selama kurun waktu 5 tahun, kedua pihak terus menjaga hubungan kerjasama tersebut meskipun terdapat berbagai kendala kecil dalam pada kenyataannya. Dari sisi koperasi terkadang tidak memenuhi standar produksi yang ditentukan oleh LPS, dan LPS pun terkadang tidak tepat waktu. Namun, kendala tersebut dapat diselesaikan dengan kompromikompromi di kedua belah pihak.

Tabel 4. Bentuk Kelembagaan dalam Sistem Pertanian Non-Pertanian dan Sistem Pertanian Padi Sehat di Kampung Ciburuy

\section{Kesimpulan}

Dari uraian di atas dapat diketahui bahwa terdapat bentuk-bentuk kelembagaan dalam sistem pertanian padi sehat yang tidak mengalami perubahan sebagaimana pada sistem pertanian padi non-organik yaitu kelembagaan penguasaan lahan, kelembagaan hubungan kerja, dan kelembagaan panen. Tata aturan dan pola-pola hubungan dalam penguasaan lahan, hubungan kerja dan panen tetap mengikuti mekanisma pada sistem pertanian nonorganik. Dengan berkembangnya sistem pertanian padi sehat, tidak merubah hubungan kerja baik sistem pembagian kerja dan sistem upah antara petani penggarap dan buruh tani. Demikian pula pada aktivitas panen.

Perbedaan tampak dengan adanya mekanisme yang membentuk kelembagaan penyedia pupuk dan pestisida, kelembagaan Koperasi Kelompok Tani "Lisung Kiwari", kelembagaan pasca panen, dan kelembagaan distribusi beras SAE sebagai produk dari padi sehat. Kelembagaankelembagaan tersebut muncul dan berkembang seiring dengan perkembangan sistem pertanian padi sehat di Kampung Ciburuy. Perbedaan tersebut tampak pada Tabel 4 berikut.

Merujuk pada bentuk-bentuk kelembagaan yang telah diuraikan, diketahui bahwa perkembangan sistem pertanian padi sehat di

\begin{tabular}{|c|c|c|c|}
\hline $\begin{array}{c}\text { Bentuk } \\
\text { Kelembagaan } \\
\end{array}$ & $\begin{array}{c}\text { Sistem Pertanian } \\
\text { Non-Organik }\end{array}$ & $\begin{array}{c}\text { Sistem Pertanian Padi } \\
\text { Sehat }\end{array}$ & $\begin{array}{l}\text { Kampung Ciburuy didukung oleh kelembagaan baik } \\
\text { pada sektor public private dan participatory. }\end{array}$ \\
\hline $\begin{array}{l}\text { Kelembagaan } \\
\text { Penyedia Pupuk } \\
\text { dan Pestisida }\end{array}$ & $\begin{array}{l}\text { Tidak ada hubungan } \\
\text { antara petani } \\
\text { penggarap dengan } \\
\text { petani peternak }\end{array}$ & $\begin{array}{l}\text { Terdapat hubungan } \\
\text { antara petani penggarap } \\
\text { dengan petani peternak } \\
\text { (kambing atau kelinci) } \\
\end{array}$ & $\begin{array}{lll}\text { Kelembagaan } & \text { sektor participatory seperti } \\
\text { kelembagaan } & \text { penyedia pupuk dan pestisida, } \\
\text { kelembagaan } & \text { penguasaan lahan, kelembagaan }\end{array}$ \\
\hline $\begin{array}{l}\text { Kelembagaan } \\
\text { Koperasi } \\
\text { Kelompok Tani } \\
\text { "Lisung Kiwari" }\end{array}$ & $\begin{array}{l}\text { Koperasi hanya } \\
\text { menyediakan input } \\
\text { produksi berupa } \\
\text { pupuk dan pestisida }\end{array}$ & $\begin{array}{l}\text { Koperasi berperan untuk } \\
\text { menyerap bantuan dana } \\
\text { pemerintah dan } \\
\text { memenuhi kebutuhan } \\
\text { modal petani, penyedia } \\
\text { input tanpa } \\
\text { menyediakan pestisida } \\
\text { kimia, berperan penting } \\
\text { membangun kerjasama } \\
\text { dengan lembaga lain } \\
\text { dalam distribusi beras } \\
\text { SAE sebagai produk } \\
\text { padi sehat }\end{array}$ & $\begin{array}{l}\text { kelompok tani, kelembagaan hubungan kerja, } \\
\text { kelembagaan panen, dan kelembagaan pasca panen } \\
\text { lebih menunjukkan terjadinya pola-pola hubungan } \\
\text { antar pelaku dengan intensitas dan derajat } \\
\text { kepentingan hubungan yang lebih tinggi. Hubungan } \\
\text { antara petani penggarap-tokoh masyarakat- } \\
\text { penyuluh-koperasi-pemilik lahan-petani peternak- } \\
\text { dan buruh tani memiliki intensitas hubungan yang } \\
\text { lebih sering dan derajat kepentingan yang tinggi } \\
\text { dalam membangun kelembagaan untuk pengaturan }\end{array}$ \\
\hline $\begin{array}{l}\text { Kelembagaan } \\
\text { Kelompok Tani }\end{array}$ & $\begin{array}{l}\text { Kelompok tani } \\
\text { kurang terorganisasi }\end{array}$ & $\begin{array}{l}\text { Kelompok tani lebih } \\
\text { terorganisasi dengan } \\
\text { terbentuknya manajer } \\
\text { pengendali mutu dan } \\
\text { adanya implikasi dari } \\
\text { kerjasama-kerjasama } \\
\text { pengembangan padi } \\
\text { sehat }\end{array}$ & $\begin{array}{l}\text { input dan produksi. Akan tetapi, kelembagaan- } \\
\text { kelembagaan tersebut sangat memerlukan dukungan } \\
\text { dari kelembagaan sektor public seperti instansi } \\
\text { pemerintah dan lembaga penyuluhan. Seperti halnya } \\
\text { instansi pemerintah memiliki intensitas hubungan } \\
\text { yang lebih jarang dan derajat kepentingan yang } \\
\text { rendah dengan petani penggarap, namun memiliki }\end{array}$ \\
\hline $\begin{array}{l}\text { Kelembagaan } \\
\text { Penyuluhan }\end{array}$ & $\begin{array}{l}\text { Metoda penyuluhan } \\
\text { yang cenderung } \\
\text { bersifat top down }\end{array}$ & $\begin{array}{l}\text { Metoda penyuluhan } \\
\text { yang lebih } \\
\text { memberdayakan dan } \\
\text { menggali partisipasi } \\
\text { petani }\end{array}$ & $\begin{array}{l}\text { intensitas hubungan dan derajat kepentingan yang } \\
\text { lebih tinggi dengan Koperasi Kelompok Tani Lisung } \\
\text { Kiwari. Hal ini ditunjukkan melalui adanya } \\
\text { mekanisme pemberian dan penyaluran dana bantuan }\end{array}$ \\
\hline $\begin{array}{l}\text { Kelembagaan } \\
\text { Pasca Panen }\end{array}$ & $\begin{array}{l}\text { Hasil panen belum } \\
\text { terkonsentrasi di } \\
\text { koperasi }\end{array}$ & $\begin{array}{l}\text { Hasil panen sebagian } \\
\text { besar di jual ke } \\
\text { koperasi, terdapat } \\
\text { aktivitas pengemasan } \\
\text { beras SAE }\end{array}$ & $\begin{array}{l}\text { dari pemerintah untuk para petani yang harus } \\
\text { melalui koperasi. Kedua lembaga merupakan } \\
\text { lembaga berbadan hukum sehingga kelembagaan } \\
\text { yang terbentuk lebih ditopang oleh aturan-aturan }\end{array}$ \\
\hline $\begin{array}{l}\text { Kelembagaan } \\
\text { Distribusi }\end{array}$ & $\begin{array}{l}\text { Belum terdapat } \\
\text { sistem distribusi } \\
\text { yang terkelola } \\
\text { dengan baik }\end{array}$ & $\begin{array}{l}\text { Terbentuk hubungan- } \\
\text { hubungan kerjasama dan } \\
\text { kemitraan dalam } \\
\text { distribusi beras SAE }\end{array}$ & yang bersifat regulatif. \\
\hline
\end{tabular}

Sumber : Data Primer, 2009 pada sektor public, private, dan participatory. Kelembagaan sektor participatory seperti kelembagaan penyedia pupuk dan pestisida, kelembagaan penguasaan lahan, kelembagaan elani, kelembagaan hubungan kerja, kepentingan hubungan yang lebih tinggi. Hubungan antara petani penggarap-tokoh masyarakatpenyuluh-koperasi-pemilik lahan-petani peternakdan buruh tani memiliki intensitas hubungan yang lebih sering dan derajat kepentingan yang tinggi dalam membangun kelembagaan untuk pengaturan input dan produksi. Akan tetapi, kelembagaankelembagaan tersebut sangat memerlukan dukungan dari kelembagaan sektor public seperti instansi pemerintah dan lembaga penyuluhan. Seperti halnya instansi pemerintah memiliki intensitas hubungan yang lebih jarang dan derajat kepentingan yang rendah dengan petani penggarap, namun memiliki intensitas hubungan dan derajat kepentingan yang lebih tinggi dengan Koperasi Kelompok Tani Lisung Kiwari. Hal ini ditunjukkan melalui adanya dari pemerintah untuk para petani yang harus melalui koperasi. Kedua lembaga merupakan lembaga berbadan hukum sehingga kelembagaan yang terbentuk lebih ditopang oleh aturan-aturan yang bersifat regulatif. 


\section{DAFTAR PUSTAKA}

Bahar, Yul Harry 2007. Pertanian Organik ataukah Pertanian Berkelanjutan ? Minggu, 4 Maret 2007.http://www.hortikultura.

go.id/index.php?option= comcontent\&task $=$ view\&id $=64 \&$ Itemid $=138$ . Di akses pada hari Senin, 12 November 2007.

Darnhofer, Ika 2005. Organic Farming and Rural Development : Some Evidence from Austria. Sociologia Ruralis, Vol 45, Number 4, October 2005. European Society for Rural Sociology. United Kingdom.

Darnhofer, Ika, Walter Schneeberger, and Bernhard Freyer 2005. Converting or Not to Organic Farming in Austria : Farmer Types and Their Rationale. Agriculture and Human Values (2006) 22:39-52. Springer: USA.

Eicher, Carl K. and John M. Staatz 1998. International Agricultural Development. John Hopkins University Press: London.

Kano, Hiroyoshi 1980. Sejarah Ekonomi Masyarakat Pedesaan Jawa : Suatu Penafsiran Kembali. Yayasan Obor Indonesia. (Hal $11-41$ ): Jakarta.

Kartini, Ni Luh. Pelestarian SDA, Kunci Pertanian Berkelanjutan dalam Kebijakan Pertanian. "Salam : Majalah Pertanian Berkelanjutan", No. 12 September 2005.

Lockie, Stewart and Darren Halpin 2005. The 'Conventionalisation' Thesis Reconsidered : Structural and Ideological Transformation of Australian Organic Agriculture. Sociologia Ruralis, Vol 45, Number 4, October 2005. European Society for Rural Sociology: United Kingdom.

Radandima, Nicolas 2003. Perubahan Kelembagaan Pertanian di Kawasan Irigasi Kambaniru : Studi Kasus di Desa Mauliru, Kabupaten Sumba Timur, Nusa Tenggara Timur. Program Pascasarjana. Institut Pertanian Bogor: Bogor.

Ropke, Jochen 1986. Perkembangan Pertanian dan Perubahan Hak Mengikuti Panen di Asia Tenggara : Budidaya Padi di Jawa. Yayasan Obor Indonesia. (Hal. 173 - 196): Jakarta.

Rukka, Hermaya 2003. Motivasi Petani dalam Menerapkan Usahatani Organik pada Padi Sawah. Tesis. Program Studi Pascasarjana. Institut Pertanian Bogor: Bogor.

Rusma, Jimmy 2005. Kajian Preferensi Konsumen Rumah Tangga terhadap Beras Organik di Kota Bogor. Tesis. Program Studi Pascasarjana. Institut Pertanian Bogor: Bogor.

Salikin, Karwan A. 2003. Sistem Pertanian Berkelanjutan. Penerbit Kanisius: Yogyakarta.

Salim, Agus. 2001. Teori dan Paradigma Penelitian Sosial. PT. Tiara Wacana. Yogyakarta.
Scott, Richard W 2008. Institutions and Organization : Ideas and Interest. Third Edition. Sage Publications: London.

Shreck, Aimee, Christy Getz, and Gail Feenstra 2006. Social Sustainability, Farm Labour, and Organic Agriculture : Findings From an Exploratory Analysis. Agriculture and Human Values (2006) 23:439-449. Springer: USA.

Sitorus, M.T Felix. 1998. Penelitian Kualitatif. Jurusan Ilmu-Ilmu Sosial Ekonomi Pertanian, Fakultas Pertanian IPB. Kelompok Dokumentasi Ilmu-Ilmu Sosial untuk Laboratorium Sosiologi, Antropologi, dan Kependudukan: Bogor.

Suhirmanto. 2003. Perubahan Preferensi Ekonomi dan Dampaknya Terhadap Stratifikasi Masyarakat. Tesis. Fakultas Pasca Sarjana. Institut Pertanian Bogor: Bogor. 